\title{
International Occupational Health and Safety Management-Systems Standards as a Frame for the Sustainability: Mapping the Territory
}

\author{
Panagiotis Marhavilas ${ }^{1, * \mathbb{C}}$, Dimitrios Koulouriotis ${ }^{1} \mathbb{D}$, Ioannis Nikolaou ${ }^{2}$ \\ and Sotiria Tsotoulidou ${ }^{3}$ \\ 1 Department of Production \& Management Engineering, Democritus University of Thrace, Vas. Sofias 12 St., \\ 67132 Xanthi, Greece; jimk@pme.duth.gr \\ 2 Department of Environmental Engineering, Democritus University of Thrace, Vas. Sofias 12 St., \\ 67132 Xanthi, Greece; inikol@env.duth.gr \\ 3 Department of Engineering Project Management, Faculty of Science \& Technology, Hellenic Open University, \\ Parodos Aristotelous 18 St., 26335 Patra, Greece; riatsotoulidou@gmail.com \\ * Correspondence: marhavil@ee.duth.gr; Tel.: +30-2541-079-410
}

Received: 29 August 2018; Accepted: 10 October 2018; Published: 12 October 2018

check for updates

\begin{abstract}
A significant part of literature has shown that the adoption of Sustainability and Health-Safety management systems from organizations bears some substantial benefits since such systems (i) create a suitable frame for the sustainable development, implementation and review of the plans and/or processes, necessary to manage occupational health-safety (OHS) in their workplaces and (ii) imply innovative thinking and practices in fields of economics, policy-making, legislation, health and education. To this context, the paper targets at analysing current sustainability and OHSMSs in order to make these issues more comprehend, clear and functional for scholars and practitioners. Therefore, a literature survey has been conducted to map the territory by focusing on two interrelated tasks. The first one includes the presentation of the main International Management Systems (IMS) with focus on Sustainability and OHS (S_OHSMS) topics and the second task depicts a statistical analysis of the literature-review findings (for the years 2006-2017). In particular, the main purposes of the literature research were: (i) the description of key points of OHSMS and sustainability standards, (ii) the comparative analysis of their characteristics, taking into account several settled evaluation-criteria and (iii) the statistical analysis of the survey's findings, while our study's primary aim is the reinforcement of OHMSs' application in any organization. The results evince, that the field of industry (with 28\%) and also of the constructions (with 16\%), concentrate the highest percentage of OHSMS use. In general, there were only few publications including OHSMSs (referred to various occupational fields) available in the scientific literature (during 2006-2017) but on the other hand, there was a gradually increasing scientific interest for these standards (especially during 2009-2012).
\end{abstract}

Keywords: Occupational Health and Safety (OHS); sustainability; Management Standards

\section{Introduction}

Occupational accidents have a key impact upon human probity, create high expenses for the social health/insurance system of any country and deteriorate the sustainability of societies. Moreover, occupational "health and safety" is one of the most vital issues in any organization (or part thereof) because it assures its continual operation, productivity and efficiency. It is known that any occupational accident or illness can affect both the employee, business operation and overall sustainability performance of firms. These disturbances, which can be valued mainly through the lost 
working-hours and the production-delays, can affect the quality of the enterprise's product [1] and the reputation of firms.

To overcome such problems, many organizations have adopted health/safety and sustainability management systems (with sufficient documentation/certification). Any organization is gradually more concerned with improving sustainability and occupational health and safety (OHS) performance and this is achieved by controlling sustainability and OHS risks, in accordance with their sustainability and OHS policy and in the context of strict legislation. There are plenty of organizations that apply sustainability and OHS reviews (or audits) to assess their sustainability and OHS performance. Nevertheless, these reviews and/or audits may not be sufficient to afford an organization with the assurance that its performance will maintain to fulfill the specific legal and policy requirements of this organization. To be efficient, they must be carried out within a structured management system that is embedded in the organization [2].

Moreover, Occupational Health and Safety Management Systems were created after a lot of well-documented and severe industrial-accidents, during the decades of 1970 and 1980 (e.g., the Flixborough Accident in 1974, the Seveso incident in 1976 and the Piper Alpha disaster in 1987). Studies and research applied on these incidents, unveiled deficiencies in main approaches concerning S_OHMS and regulation and revealed the need to approve approaches which thoroughly addressed both education and engineering responses. The propagation of OHS management systems that have been observed globally since the decade of 1990 [3], has noticeably increased the focus on techniques (and/or tools) concerning performance measurement [4].

A Health and Safety Management System provides a framework for managing health and safety risk. Generally speaking, we can consider the term "risk" as the likelihood that someone (or something) will be harmfully affected by the hazard, while "hazard" is any insecure condition (or source of undesirable/adverse events) with strong potential for creating harm or damage. Alternatively, "risk" would be defined as a measure (under ambiguity) of the hazard severity or a measure of the likelihood and consequence of injurious/adverse effects [5-8].

Public interest in the field of risk analysis and assessment (RAA) has been expanded during the last four decades, so that risk analysis constitutes an efficient and widespread procedure that completes the whole management of nearly all aspects of our life. Thus, almost all managers (e.g., of health care, environment, physical infrastructure systems, etc.) incorporate RAA techniques in their decision-making process. In addition, the universal adjustments of risk analysis by many disciplines (like industry, government agencies) in decision-making, have led to a unique development of theory and methodology and also of practical tools [8].

According to P. Marhavilas [9], risk analysis is a vital process for the safety strategy of any firm, having as main objective the elimination of any potential of damage or harm in its production, while the quantified risk evaluation apparently is the most critical part of the entire procedure of assessing occupational hazards and/or unsafe situations in the workplaces. Furthermore, a complex human-machine system that is composed of humans, machines and their interaction, could suitably be expressed by a system model. Therefore, RAA constitutes a substantial tool for the safety strategy of an organization and also for the assessment process of the occurrence, the consequences and the impact of human activities on systems with hazardous features.

The introduction of a management system in any organization provides a frame for the sustainable development, implementation, sustainability and review of the plans and/or processes which are essential for the occupational health-safety (OHS) management in the workplaces. Since the appearance of such systems during the decade of 1970, significant growth of the approach has occurred, driven by the following factors: (i) OHS is affected by all aspects of the design and functioning of an organization, (ii) the design and management of health and safety systems must associate people, environment and also technical systems in extent that reveal an organization's unique features, (iii) health and safety is a management function and requires broad management involvement, (iv) accidents, injuries and 
diseases are an indication of a problem in the system and are not coming from a human error and (vi) performance goals must illustrate management objectives [10].

The international management systems (IMS) standards, covering the field of occupational health and safety (OHS) in worksites, are intended to provide organizations and enterprises with elements of an effective occupational health and safety management system (OHSMS) that can be associated (or integrated) with other management requirements and help organizations achieve OHS and economic objectives.

The S_OHSMS standards specify requirements for an OHS management system, in order to allow an organization to develop and implement a strategy which take into account legal requirements about OHS risks. These are intended to apply to all types of corporations and to establish various geographical, cultural and social conditions. Such a system enables a corporation to create an OHS strategy, develop objectives, scopes and processes to achieve the policy obligations, take action as needed to improve its performance and demonstrate the compliance of the system to the requirements of this OHSMS standard. Moreover, the general aim of OHSMS standards is to support capable OHS practices, in the framework of socio-economic needs [2].

The British Safety Council (BSC) and the International Labour Organisation (ILO) made a research in which valued the rewards of the prevention of accidents and/or diseases in enterprises within a period of 2 years. This study shows that the corporation which had adopted such a safety management system had the following results [11]: (i) productivity improvement, (ii) significant reduction of the frequency of cases of absence, (iii) significant reduction of compensation claims and insurance costs, (iv) improvement of the psychology of labor in addition with the increase of morale and concentration at work and (v) improving the company image to customers and suppliers.

In this work, the foremost IMS standards of promoting sustainability and OHS are presented, on the one hand and on the other side, the statistical results of a research (literature survey), reviewing vicarious scientific journals (for years 2006-2017). Thus, the main aim of our study is the strengthening of OHSM standards' application, in any organization (i.e., of any type and size).

The rest of the paper consists of five sections including (i) an overview of the OHSMS standards, (ii) a methodology (iii) the results of a statistical analysis, (v) the discussion and (vi) the conclusions.

\section{Theoretical Background}

A significant part of literature focuses on RAA of sustainability and health/safety accidents. The growing complexity of services, processes and products, entering the market, requires that the safety aspects must be considered with high priority. Undoubtedly, there is no absolute safety, so that some risk always remains in a specific worksite, constituting the "residual risk." Thus, any service, process and/or product can only be relatively safe. To continue, relative safety is achieved by risk degradation to a tolerable level, which is called as "tolerable risk," which is defined by the exploration of the finest balance between the ideal safety and the demands to be met by a service/process/product and factors such as profit for the user and cost effectiveness. Tolerable risk is succeeded by the procedure of risk assessment (risk analysis and risk evaluation) and risk reduction [12], while "risk management" can be considered as the entire methodology that includes both "qualitative" and "quantitative analysis techniques" [13-15].

In the scientific literature, four phases are prominent, as far as quantitative risk assessment is concerned (see for example the works [9,16-18]) depicted as follows: (a) Qualitative analysis, that incorporates the system definition and its scope, the hazards identification/description and the failure scenarios as well. (ii) Quantitative analysis, which incorporates the probabilities determination and the consequences of the defined undesirable events and also the risk quantification by a number (i.e., the risk quantity) or by a graph as a function of probabilities and consequences. (iii) Risk evaluation, which incorporates the evaluation process, on the base of the results of the former analysis. (iv) Risk control and reduction phase, which includes the step of taking measures (in order to be reduced the 
risk) and taking into account how the risks can be controlled (for example by inspection, maintenance or warning systems).

According to the IEC [15] the concept of risk presents two components that is, the frequency (or probability) that a harmful event (or an unsafe situation) is expected to occur and the consequences of this event. Moreover, CCPS [19] determines the risk as a measure of economic loss or human hurt in the frame of the likelihood and the magnitude of the loss (or damage).

To eliminate risks from sustainability and Health and Safety problems, a number of management systems has been proposed. In general, a management system is the methodology or the way by which an organization manages its internal procedures (or subjects) in order to achieve its objectives, which are associated with a number of different topics (including service quality or product quality, operational capability, environmental accomplishment, health and safety in the workplaces, et cetera). The level of the system's intricacy will depend on each organization's specific context. In small organisations, there is no (or less) need for extensive documentation because it is transparent how the employees contribute to the organization's overall aims. On the other side, more complicated corporations operating, may need extensive documentation in order to accomplish their organizational goals. Moreover, international management system (IMS) standards help organizations improve their performance by specifying repeatable steps that organizations consciously implement to accomplish their aims and to develop an organizational culture [20].

According to Gallagher [21], OHSM systems have been defined as "a combination of the planning and review, the management organizational arrangements, the consultative arrangements and the specific program elements that work together in an integrated way to improve health and safety performance."

Table 1 presents an overview of the most important worldwide OHSMS standards, based on selected information that has been collected from various sources and from the review of scientific literature as well.

Table 1. An overview of OHSMS standards.

\begin{tabular}{|c|c|c|c|c|c|}
\hline Codes & Edition Year & Institutions & Description & Focus & Reference \\
\hline BS 8800 & $\begin{array}{l}1996 \text { (as BS } \\
\text { 8800:1996) and } \\
\text { revised in 2004 (as BS } \\
\text { 8800:2004) and in } \\
\text { 2008 (as BS } \\
\text { 18004:2008). }\end{array}$ & BSI & $\begin{array}{l}\text { "It gives guidance on OHS } \\
\text { management systems for assisting } \\
\text { compliance with stated OHS policies } \\
\text { and objectives and on how OHS should } \\
\text { be integrated within the organization's } \\
\text { overall management system" }\end{array}$ & $\begin{array}{c}\text { Social } \\
\text { dimension }\end{array}$ & [22-24] \\
\hline HSG 65 & $\begin{array}{c}1991 \text { and revised in } \\
\text { the years } 1997 \text { and } \\
2013 .\end{array}$ & HSE & $\begin{array}{l}\text { "A useful guide for directors, managers, } \\
\text { health/safety professionals and } \\
\text { employee representatives who wanted } \\
\text { to improve health and safety in their } \\
\text { organizations" }\end{array}$ & $\begin{array}{c}\text { Social } \\
\text { dimension }\end{array}$ & {$[25,26]$} \\
\hline $\begin{array}{l}\text { OHSAS } \\
18001\end{array}$ & $\begin{array}{l}\text { The first edition } \\
\text { (OHSAS 18001:1999) } \\
\text { has been technically } \\
\text { revised and replaced } \\
\text { by the OHSAS } \\
\text { 18001:2007 edition } \\
\text { (second one). }\end{array}$ & $\begin{array}{l}44 \text { cooperating } \\
\text { organizations } \\
\text { (constituting } \\
\text { OHSAS Project } \\
\text { Group) }\end{array}$ & $\begin{array}{l}\text { "It is based on (i) "Plan": establish the } \\
\text { aims and processes which are essential } \\
\text { for the achievement in accordance with } \\
\text { the organization's OHS policy, (ii) "Do": } \\
\text { implement the processes, (iii) "Check": } \\
\text { monitor and measure processes against } \\
\text { OHS policy, objectives, legal and other } \\
\text { requirements and report the results, (iii) } \\
\text { "Act": take actions to continually } \\
\text { improve OHS performance" }\end{array}$ & $\begin{array}{c}\text { Social } \\
\text { dimension }\end{array}$ & [2] \\
\hline $\begin{array}{l}\text { ILO-OSH } \\
2001\end{array}$ & $\begin{array}{l}2001 \text { and revised in } \\
2009 .\end{array}$ & ILO & $\begin{array}{l}\text { "It provides a unique and powerful } \\
\text { instrument for the development of a } \\
\text { sustainable safety culture within } \\
\text { organizations. The practical } \\
\text { recommendations of these guidelines } \\
\text { are intended for use by all those who } \\
\text { have responsibility for occupational } \\
\text { safety and health management" }\end{array}$ & $\begin{array}{c}\text { Social } \\
\text { dimension }\end{array}$ & [27] \\
\hline
\end{tabular}


Table 1. Cont

\begin{tabular}{|c|c|c|c|c|c|}
\hline Codes & Edition Year & Institutions & Description & Focus & Reference \\
\hline $\begin{array}{l}\text { AS/NZS } \\
4801: 2001\end{array}$ & 2001 & AS/NZS & $\begin{array}{l}\text { "The scope of this standard is to set } \\
\text { auditable criteria for an OHSMS. It is a } \\
\text { specification that aims to cover the best } \\
\text { elements of such systems already } \\
\text { widely used in New Zealand and } \\
\text { Australia. It incorporates guidance on } \\
\text { how those criteria may be } \\
\text { accomplished" }\end{array}$ & $\begin{array}{c}\text { Social } \\
\text { dimension }\end{array}$ & [28] \\
\hline $\begin{array}{c}\text { ANSI/ } \\
\text { AIHA } \\
\text { Z10-2005 }\end{array}$ & $\begin{array}{l}2005 \text { and revised in } \\
2012\end{array}$ & ANSI & $\begin{array}{l}\text { "Significant features that define Z10 } \\
\text { include focus on management } \\
\text { leadership roles, efficient employee } \\
\text { participation, design review and } \\
\text { change. It provides a tool to help } \\
\text { organizations create and develop OHS } \\
\text { performance" }\end{array}$ & $\begin{array}{c}\text { Social } \\
\text { dimension }\end{array}$ & {$[29,30]$} \\
\hline $\begin{array}{c}\text { Une } \\
\text { 81900:1996 } \\
\text { EX }\end{array}$ & 1996 & AENOR & $\begin{array}{l}\text { “- UNE 81900:1996 EX: Prevention of } \\
\text { Occupational Hazards. Rules for the } \\
\text { implementation of a SGPRL. } \\
\text { - UNE 81901:1996 EX: Prevention of } \\
\text { Occupational Hazards. General Rules } \\
\text { for the Evaluation of SGPRLs. } \\
\text { - UNE 81902:1996 EX: Prevention of } \\
\text { Occupational Hazards. Vocabulary. } \\
\text { - BUNE 81903:1997 EX: Prevention of } \\
\text { Occupational Hazards. General Rules } \\
\text { for the Evaluation of a SGPRL. Criteria } \\
\text { for the qualification of the Auditors of } \\
\text { Prevention. } \\
\text { - UNE 81904:1997 EX: Prevention of } \\
\text { Occupational Hazards. General Rules } \\
\text { for the Evaluation of SGPRLs. } \\
\text { Management of audit programs. } \\
\text { - UNE 81905:1997 EX: Prevention of } \\
\text { Occupational Hazards. Guide for the } \\
\text { implementation of a SGPRL” }\end{array}$ & $\begin{array}{c}\text { Social } \\
\text { dimension }\end{array}$ & [33] \\
\hline Uni 10616 & $\begin{array}{l}1997 \text { (and withdrawn } \\
\text { in } 2012\end{array}$ & UNI & $\begin{array}{l}\text { "Some of the major qualifying points } \\
\text { are: (i) Espousal of inherent safety } \\
\text { principles. (ii) Espousal of matrices or } \\
\text { risk charts for assessing the } \\
\text { acceptability/tolerability of risks. (iii) } \\
\text { Definition of inspection activities and } \\
\text { periodic checks of critical lines and } \\
\text { equipment. (iv) The assessment of the } \\
\text { external domino effect between } \\
\text { neighbouring plants, (v) The adoption } \\
\text { of a work-permission system, (vi) } \\
\text { Selection of suppliers of goods and } \\
\text { services such as companies, companies, } \\
\text { builders, consortia, (vii) Adopting } \\
\text { procedures for periodic internal } \\
\text { auditing with internal or external } \\
\text { auditors" }\end{array}$ & $\begin{array}{c}\text { Social } \\
\text { dimension }\end{array}$ & [34] \\
\hline
\end{tabular}


Table 1. Cont.

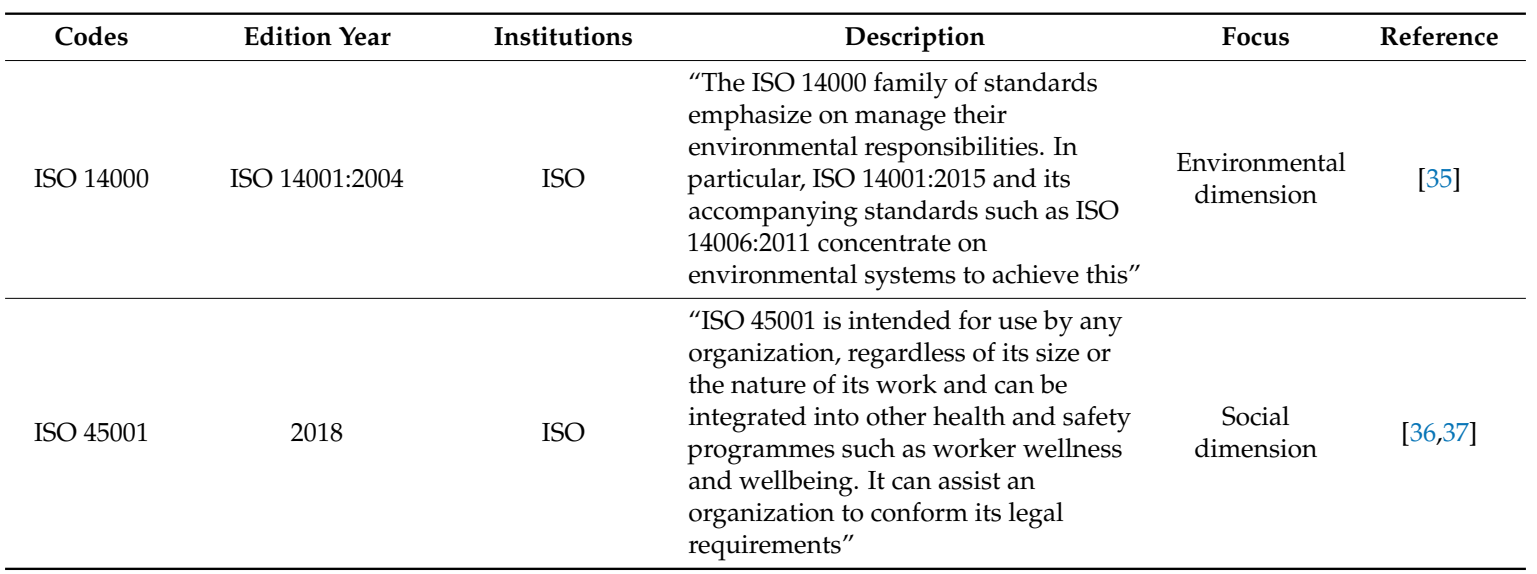

Over the past three decades, the use of OHSMS has become common in worksites in the developed economies, noting the fundamental elements of a OHSMS [38]. It is worth noting that many international management system standards have contiguous structure, containing a large number of the same terms and definitions. These characteristics are helpful for those organizations that operate an "integrated" management system [20] which can merge the requirements of two or more management system standards simultaneously (for example OHS with Environmental, or OHS with Quality management systems).

In Table 2 we depict the evolution of the OHSMS standards throughout the years 1990-2018. More specifically, the symbols " -" denote (in association with the year) the nonexistence of a standard, while the symbols " +" the appearance of the standard. In addition, the symbols ",++ " "+++," "++++" and ",$+++++ "$ denote the 1st, the 2nd, the 3rd and the 4th update of it, correspondingly.

Table 2. The evolution of the OHSMS standards throughout the years 1990-2018.

\begin{tabular}{|c|c|c|c|c|c|c|c|c|c|c|c|}
\hline Year & $\begin{array}{c}\text { ISO } \\
14001\end{array}$ & $\begin{array}{c}\text { ILOOSH } \\
2001\end{array}$ & $\begin{array}{c}\text { BS } \\
8800\end{array}$ & $\begin{array}{c}\text { OHSAS } \\
18001\end{array}$ & HSG65 & $\begin{array}{c}\text { ANSI/AIHA } \\
\text { Z10 }\end{array}$ & $\begin{array}{c}\text { AS/NZS } \\
4801\end{array}$ & $\begin{array}{c}\text { SS } \\
506\end{array}$ & $\begin{array}{c}\text { Une } \\
81900\end{array}$ & $\begin{array}{c}\text { Uni } \\
10616\end{array}$ & $\begin{array}{c}\text { ISO } \\
45001\end{array}$ \\
\hline 1990 & - & - & - & - & - & - & - & - & - & - & - \\
\hline 1991 & - & - & - & - & + & - & - & - & - & - & - \\
\hline 1992 & + & - & - & - & + & - & - & - & - & - & - \\
\hline 1993 & + & - & - & - & + & - & - & - & - & - & - \\
\hline 1994 & + & - & - & - & + & - & - & - & - & - & - \\
\hline 1995 & ++ & - & - & - & + & - & - & - & - & - & - \\
\hline 1996 & +++ & - & + & - & + & - & - & - & + & - & - \\
\hline 1997 & +++ & - & + & - & ++ & - & - & - & + & + & - \\
\hline 1998 & +++ & - & + & - & ++ & - & - & - & + & + & - \\
\hline 1999 & +++ & - & + & + & ++ & - & + & - & + & + & - \\
\hline 2000 & +++ & - & + & + & ++ & - & ++ & - & + & + & - \\
\hline 2001 & +++ & + & + & + & ++ & - & +++ & - & + & + & - \\
\hline 2002 & +++ & + & + & + & ++ & - & +++ & - & - & + & - \\
\hline 2003 & +++ & + & + & + & ++ & - & +++ & - & - & + & - \\
\hline 2004 & ++++ & + & ++ & + & ++ & - & +++ & + & - & + & - \\
\hline 2005 & ++++ & + & ++ & + & ++ & + & +++ & + & - & + & - \\
\hline 2006 & ++++ & + & ++ & + & ++ & + & +++ & + & - & + & - \\
\hline 2007 & ++++ & + & ++ & ++ & ++ & + & +++ & + & - & + & - \\
\hline 2008 & ++++ & + & +++ & ++ & ++ & + & +++ & + & - & + & - \\
\hline 2009 & ++++ & ++ & +++ & ++ & ++ & + & +++ & ++ & - & + & - \\
\hline 2010 & ++++ & ++ & +++ & ++ & ++ & + & +++ & ++ & - & + & - \\
\hline 2011 & ++++ & ++ & +++ & ++ & ++ & + & +++ & ++ & - & + & - \\
\hline 2012 & ++++ & ++ & +++ & ++ & ++ & ++ & +++ & ++ & - & - & - \\
\hline 2013 & ++++ & ++ & +++ & ++ & +++ & ++ & +++ & ++ & - & - & - \\
\hline 2014 & ++++ & ++ & +++ & ++ & +++ & ++ & +++ & ++ & - & - & - \\
\hline 2015 & +++++ & ++ & +++ & ++ & +++ & ++ & +++ & ++ & - & - & - \\
\hline 2016 & +++++ & ++ & +++ & ++ & +++ & ++ & +++ & ++ & - & - & - \\
\hline 2017 & +++++ & ++ & +++ & ++ & +++ & ++ & +++ & ++ & - & - & - \\
\hline 2018 & +++++ & ++ & +++ & ++ & +++ & ++ & +++ & ++ & - & - & + \\
\hline
\end{tabular}

Annotations: the symbols "-," "+," ",++ " ",+++ " " ++++ " and ",+++++ " denote the nonexistence, the appearance, the 1 st, the 2 nd, the 3 rd and the 4 th update of a standard, respectively. 


\section{Methodology}

Today, OHS issues are considered very important for organizations for economic (e.g., decrease lost working days), environmental (e.g., environmental hazards for employees) and social issues (e.g., ethical working conditions). It is well known that the major body of relevant literature focuses on the regulatory requirements of organizations regarding OHS issues, while a smaller part of the literature emphasizes on voluntary initiatives of organization on OHS issues. However, the voluntary trend of organizations has lately gained ground under the context of social responsibility of organizations to contribute to sustainable development [39]. This is integrated into the context of organizations as a commitment to OHS issues beyond the law which should be achieved through voluntary implementation of OHS standards (e.g., OSHAS 18001, ISO 45001). To this end, the suggested research methodology recommends sustainability concept as a frame to examine a set of current OHS standards (Table 1) through: (a) environmental dimension of sustainability (ISO 14001) and (b) social dimension of sustainability (BS 8800; HSG 65; OHSAS 18001; ILO-OSH 2001; ASINZS 4801; SS506; Une 81900: 1996 EX; Uni10616 and ISO 45001). It is necessary to clarify that the sustainability concept is only utilized as a frame of analysis and classification of OHS standards and none effort has been made to explain how the OHS examined standards contribute to aspects of sustainable development.

Additionally, the suggested research methodology is based on three sequential steps. The first step pertains the selection of journals, the second includes the appropriate keywords for addressing research questions and the third shows the coding method. In particular, the review of the scientific literature was accomplished by the research of ten representative scientific journals which focus on sustainability and health and safety issues (Table 3). The selection of these papers was based on the following two criteria: (a) the focusing on health and safety issues and sustainability and (b) the existence of high impact among scholars (Q1 and high impact factor). More specifically, taking into account that few other systematic (e.g., [3]) or narrative (e.g., [40-43]) literature reviews exist, on the topic of OHSMS standards, the time period before the year 2006, we investigated and studied published articles of the previous referred journals, collecting a large number of around $\mathrm{N}=9822$ papers, throughout the years 2006-2017.

Table 3. The ten investigated journals/sources (throughout the years 2006-2017).

\begin{tabular}{ccc}
\hline $\mathbf{N r}$ & Source & Publisher \\
\hline 1 & "Applied Ergonomics" & \\
2 & "Accident Analysis and Prevention" & \\
3 & "Journal of Cleaner Production" & \\
4 & "Journal of Operations Management" & "Safety Science" \\
6 & "Journal of Loss Prevention in the Process & "Elsevier B.V." \\
7 & "Industries" & \\
8 & "Journal of Safety Research" & \\
\hline 9 & "Architectural Science Review" & "Taylor \& Francis" \\
\hline 10 & "Professional Safety" & "American Society of Safety Engineers" \\
\hline
\end{tabular}

In particular, the methodological steps of the survey included: (i) investigation of the literature (e.g., through SCOPUS); (ii) screening the journals with the highest number of articles and the most important studies on S_OHSMS standards; (iii) selection of relevant studies; (iv) appraisal of the quality of the research evidence in the studies. The appropriate keywords we used in the survey were "Occupational Health and Safety", "Sustainability", "Management Standards".

\section{Results}

The procedure of reviewing the scientific literature, unveiled only a few published papers on OHSMS standards referred to many different fields (like construction, industry, engineering, 
transportation, chemistry, oil and refinery, food sector, et cetera). These papers address concepts, tools and methodologies that have been created and practiced in such areas as design, development, quality-control and maintenance, in association with occupational risk assessment.

The different OHSMS standards follow, in general, similar paths between "start" and "finish." Taking into account the results of our literature review, we present in the following Table 4, the comparison between the above referred OHSMS standards. This table depicts an overview of their features, comparatively with several settled evaluation-criteria.

Table 4. Comparison of OHSMS Standards.

\begin{tabular}{|c|c|c|c|c|c|c|c|c|}
\hline \multirow[b]{2}{*}{ Characteristics } & \multicolumn{8}{|c|}{ OHSMS Standards } \\
\hline & ISO 14001 & ILOOSH 2001 & BS 8800 & OHSAS 18001 & HSG65 & $\begin{array}{c}\text { ANSI/ } \\
\text { AIHA Z10 }\end{array}$ & $\begin{array}{c}\text { AS/NZS } \\
4801\end{array}$ & SS 506 \\
\hline $\begin{array}{c}\text { General } \\
\text { requirements }\end{array}$ & YES & NO & NO & YES & NO & NO & NO & NO \\
\hline $\begin{array}{l}\text { Initial or periodic } \\
\text { status review }\end{array}$ & NO & NO & YES & NO & YES & NO & NO & $\mathrm{NO}$ \\
\hline $\begin{array}{l}\text { Management } \\
\text { leadership and } \\
\text { Labour } \\
\text { participation }\end{array}$ & NO & NO & NO & NO & NO & YES & NO & NO \\
\hline Policy & YES & YES & YES & YES & YES & NO & YES & YES \\
\hline Organising & $\mathrm{NO}$ & YES & YES & NO & YES & NO & $\mathrm{NO}$ & NO \\
\hline Planning & YES & YES & YES & YES & YES & YES & YES & YES \\
\hline $\begin{array}{c}\text { Implemention/ } \\
\text { Operation }\end{array}$ & YES & YES & YES & YES & YES & YES & YES & YES \\
\hline $\begin{array}{l}\text { Inspection and } \\
\text { Evaluation }\end{array}$ & YES & YES & NO & YES & NO & YES & YES & YES \\
\hline $\begin{array}{l}\text { Performance } \\
\text { measurement }\end{array}$ & NO & NO & YES & NO & YES & NO & YES & NO \\
\hline $\begin{array}{l}\text { Improvement } \\
\text { actions }\end{array}$ & NO & YES & NO & NO & NO & NO & $\mathrm{NO}$ & $\mathrm{NO}$ \\
\hline Corrective actions & YES & NO & NO & YES & NO & YES & NO & YES \\
\hline $\begin{array}{l}\text { Management } \\
\text { Review }\end{array}$ & YES & NO & NO & YES & YES & YES & YES & YES \\
\hline Audit & NO & NO & YES & NO & YES & NO & NO & NO \\
\hline $\begin{array}{l}\text { Continuous } \\
\text { Improvement }\end{array}$ & YES & NO & NO & YES & NO & YES & YES & YES \\
\hline $\begin{array}{l}\text { Performance } \\
\text { inspection }\end{array}$ & YES & YES & YES & YES & YES & YES & YES & YES \\
\hline Origin & International & International & UK & International & UK & USA & $\begin{array}{l}\text { Australia/ } \\
\text { New } \\
\text { Zealand }\end{array}$ & Singapore \\
\hline $\begin{array}{c}\text { Year of } \\
\text { establishment }\end{array}$ & 1992 & 2001 & 1996 & 1999 & 1991 & 2005 & 1999 & 2004 \\
\hline Update & YES & YES & YES & YES & YES & YES & YES & YES \\
\hline $\begin{array}{l}\text { Good embedded } \\
\text { OHS practices }\end{array}$ & NO & YES & YES & YES & NO & YES & NO & YES \\
\hline Weak issues & YES & YES & YES & YES & YES & YES & YES & YES \\
\hline $\begin{array}{l}\text { Glossary Terms } \\
\text { and definitions }\end{array}$ & YES & YES & YES & YES & NO & NO & NO & NO \\
\hline $\begin{array}{c}\text { Workers } \\
\text { participation }\end{array}$ & NO & YES & NO & NO & NO & NO & NO & NO \\
\hline Documentation & YES & YES & YES & YES & YES & YES & YES & YES \\
\hline $\begin{array}{c}\text { Free of Charge } \\
\text { Manual }\end{array}$ & NO & YES & NO & NO & NO & NO & NO & NO \\
\hline $\begin{array}{l}\text { Risk assessment } \\
\text { technique }\end{array}$ & NO & NO & YES & YES & NO & YES & NO & NO \\
\hline $\begin{array}{l}\text { Application on } \\
\text { Organisations of } \\
\text { any type and size }\end{array}$ & NO & YES & YES & YES & NO & YES & $\mathrm{NO}$ & YES \\
\hline
\end{tabular}


Table 4. Cont.

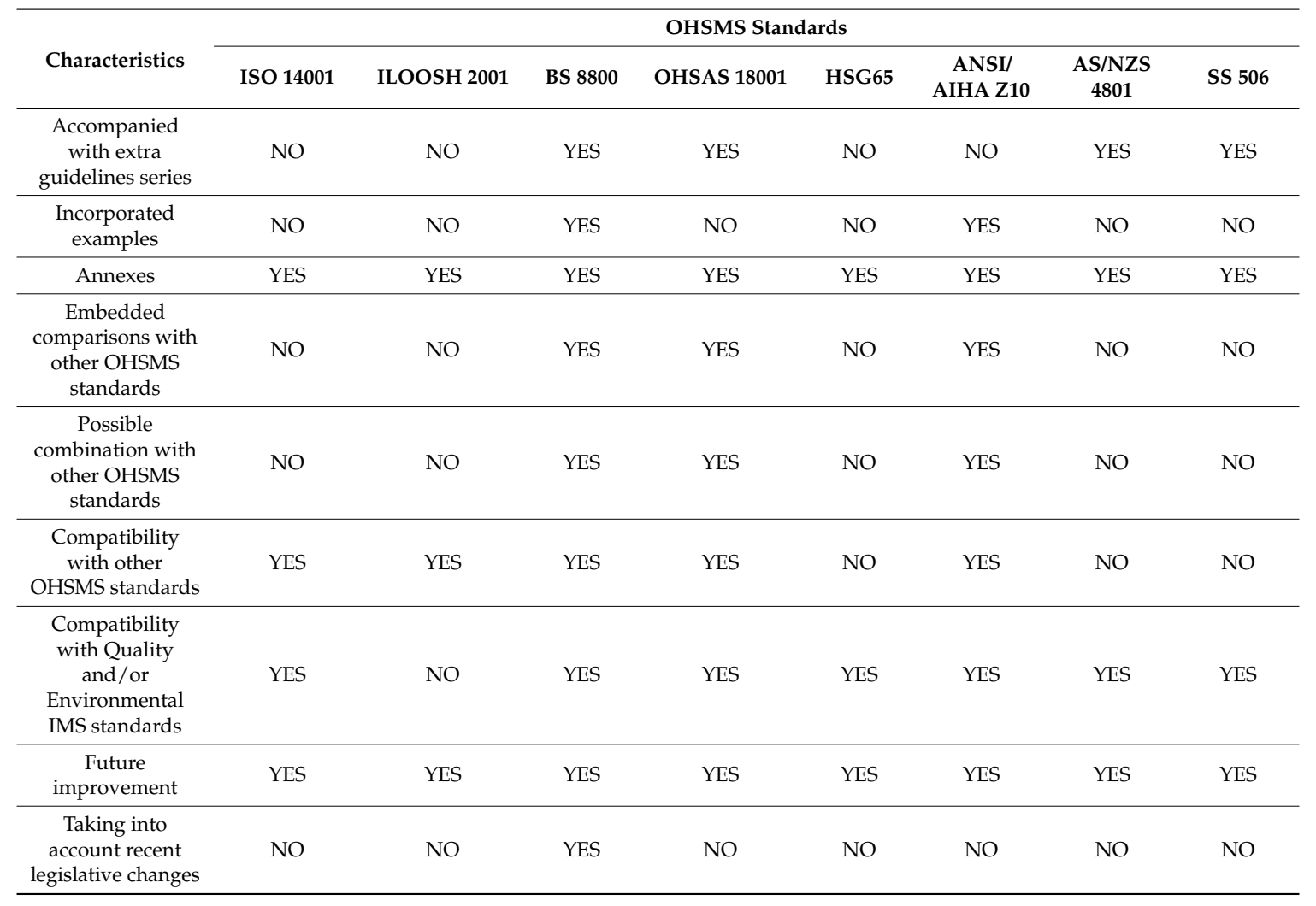

The investigation of the scientific literature revealed $S=75$ published technical articles which were associated with OHSMS Standards in the worksites and concerned many different fields (like construction, chemistry, engineering, transportation, medicine, etc.).

In Appendix A (Table A1) we show the classification results of the 75 articles incorporating OHSMS standards which were defined by the investigation of $\mathrm{N}=9822$ papers of ten sources covering the time period 2006-2017. Table A1 uses eight columns for example, the number (or numerical code) of the paper (A), the paper's citation information (columns B, C, D), the OHSMS standard's name (E), the kind of the paper's data or material (F), the field of application $(\mathrm{G})$ and the source (journal's name) [column H].

In Appendix B (Table A2) we illustrate the statistical results of the survey including the following:

(i) the absolute frequency $\mathrm{N}_{\mathrm{i}}$ that is, the number of investigated papers per journal (col. $\mathrm{C}$, that is, JAE: 886; AAP: 1522; JCP: 1005; JOM: 995; ASR: 1007; JSS: 945; JPS: 998; JLPPI: 881; IJIE: 955; JSR: 628),

(ii) the relative frequency $\mathbf{F}_{\mathbf{i}}=\mathbf{N}_{\mathbf{i}} / \mathbf{N}$ of the ten journals, concerning the total amount of the published papers during 2006-2017 (column D, that is, JAE: 9.02\%; AAP: $15.50 \%$; JCP: $10.23 \%$; JOM: $10.13 \%$; ASR: $10.25 \%$; JSS: 9.62\%; JPS: 10.16\%; JLPPI: $8.97 \%$; IJIE: 9.72\%; JSR: 6.39\%),

(iii) the number of papers $\mathrm{n}_{\mathrm{ST}(\mathrm{i})}$ concerning OHS which include or use or refer to OHSMS standards (column E, that is, JAE: 3; AAP: 8; JCP: 3; JOM: 1; ASR: 1; JSS: 40; JPS: 4; JLPPI: 8; IJIE: 1; JSR: 6),

(iv) the relative occurrence frequency of papers (referred to $\mathrm{N}$ ) which include (or use or refer to) OHSMS-standards $\mathbf{f}_{\mathbf{S T}(\mathbf{i})}=\mathbf{n}_{\text {STS(i) }} / \mathbf{N}$ (column F, that is, JAE: $0.03 \%$; AAP: $0.08 \%$; JCP: $0.03 \%$; JOM: 0.01\%; ASR: 0.01\%; JSS: 0.41\%; JPS: 0.04\%; JLPPI: 0.08\%; IJIE: 0.01\%; JSR: $0.06 \%$,

(v) the normalized (per journal) occurrence frequency of papers which include OHSMS standards $\mathbf{f}_{\mathbf{i}}{ }^{*}=\mathbf{n}_{\mathbf{S T}(\mathbf{i})} / \mathbf{N}_{\mathbf{i}}$ (column F, that is, JAE: $0.34 \%$; AAP: $0.53 \%$; JCP: $0.30 \%$; JOM: $0.10 \%$; ASR: $0.10 \%$; JSS: $4.23 \%$; JPS: $0.40 \%$; JLPPI: $0.91 \%$; IJIE: $0.10 \%$; JSR: $0.96 \%$ ), 
(vi) the relative occurrence frequency of papers (referred to S) which include OHSMS standards $\mathbf{f}^{* *}$ ST(i) $=\mathbf{n}_{\text {ST(i) }} / \mathbf{S}$ (column F, that is, JAE: $4.00 \%$; AAP: $10.67 \%$; JCP: $4.00 \%$; JOM: $1.33 \%$; ASR: 1.33\%; JSS: $53.33 \%$; JPS: 5.33\%; JLPPI: 10.67\%; IJIE: 1.33\%; JSR: $8.00 \%$ ).

Moreover, Figure 1 illustrates for the time period of 2006-2017 the following: (a) the relative frequency $\mathrm{F}_{\mathrm{i}}=\mathrm{N}_{\mathrm{i}} / \mathrm{N}$ of the ten journals, concerning the total amount of their published articles, (b) the relative occurrence frequency of papers (referred to N) with OHSMS-standards $\mathrm{f}_{\mathrm{ST}(\mathrm{i})}=\mathrm{n}_{\mathrm{ST}(\mathrm{i})} / \mathrm{N}$, (c) the normalized (per journal) occurrence frequency of papers concerning OHS which include OHSMS standards $\mathrm{f}_{\mathrm{i}}{ }^{*}=\mathrm{n}_{\mathrm{ST}(\mathrm{i})} / \mathrm{N}_{\mathrm{i}}(\mathrm{d})$ the relative occurrence frequency of papers (referred to $\mathrm{S}$ ) which include OHSMS standards $\mathrm{f}^{* *} \mathrm{ST}(\mathrm{i})=\mathrm{n}_{\mathrm{ST}(\mathrm{i})} / \mathrm{S}$, (e) the relative occurrence-frequency of the various OHSMS standards (which are included in the above referred $S=75$ papers) and (f) the percentage distribution of the papers with OHSMS standards in association with different types of data.

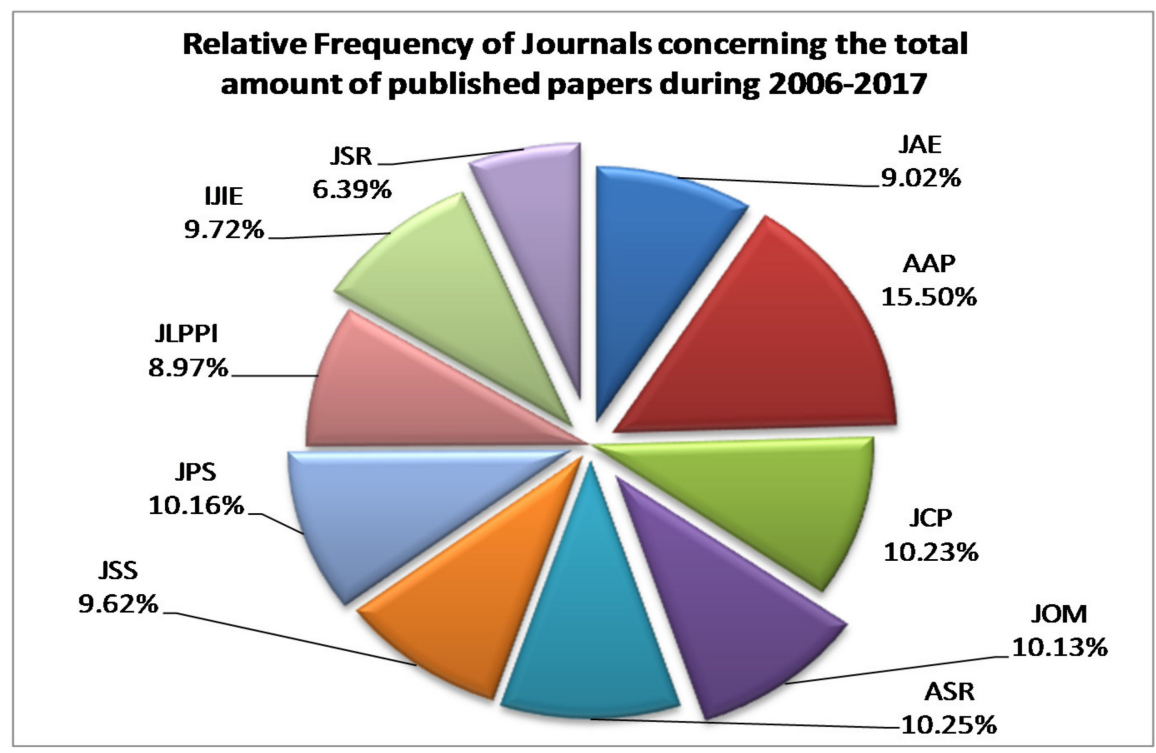

(a)

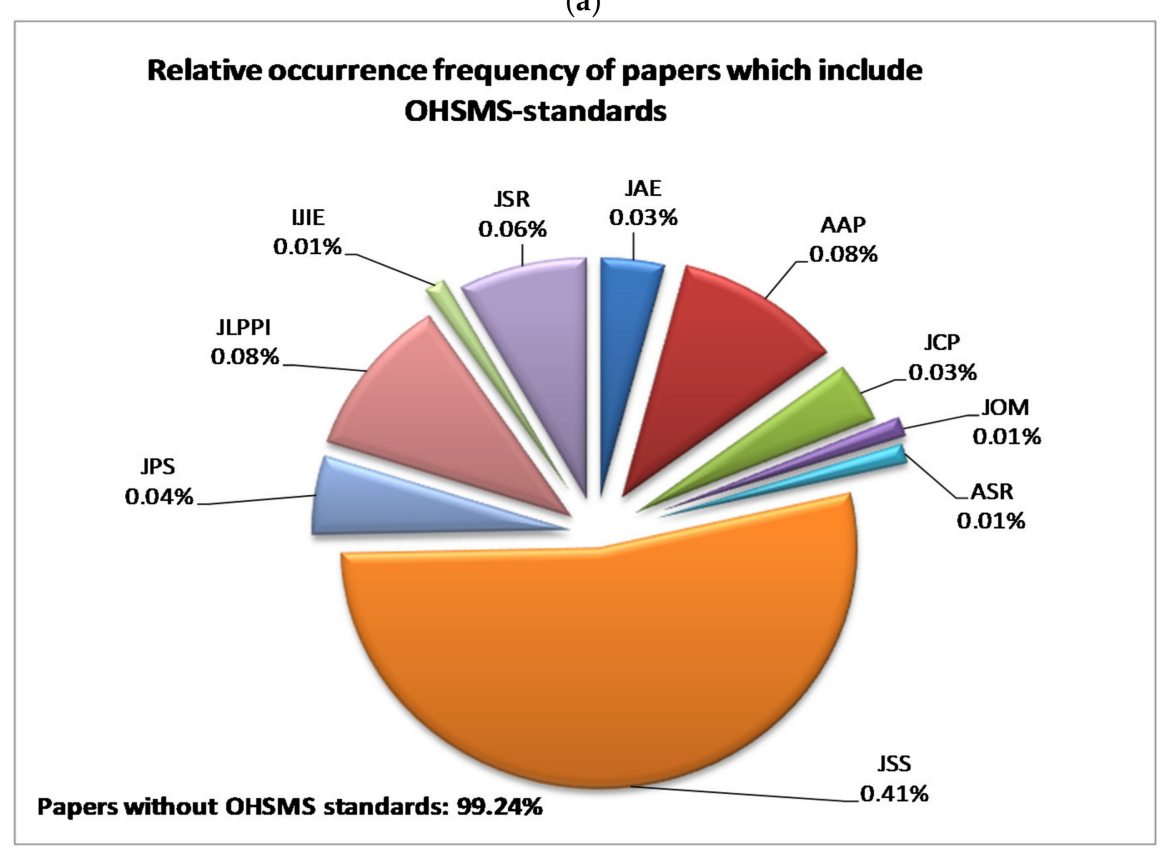

(b)

Figure 1. Cont. 


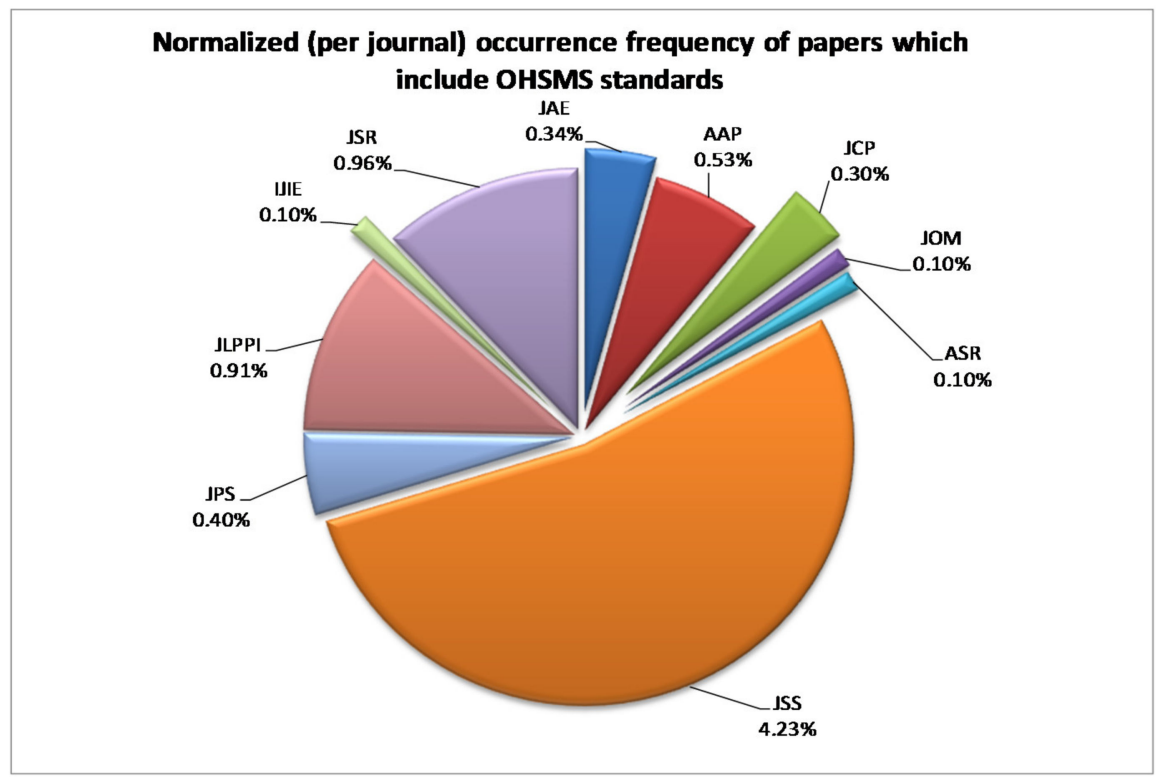

(c)

Relative occurrence frequency of papers concerning OHS which include or use OHSMS standards (referred to S)

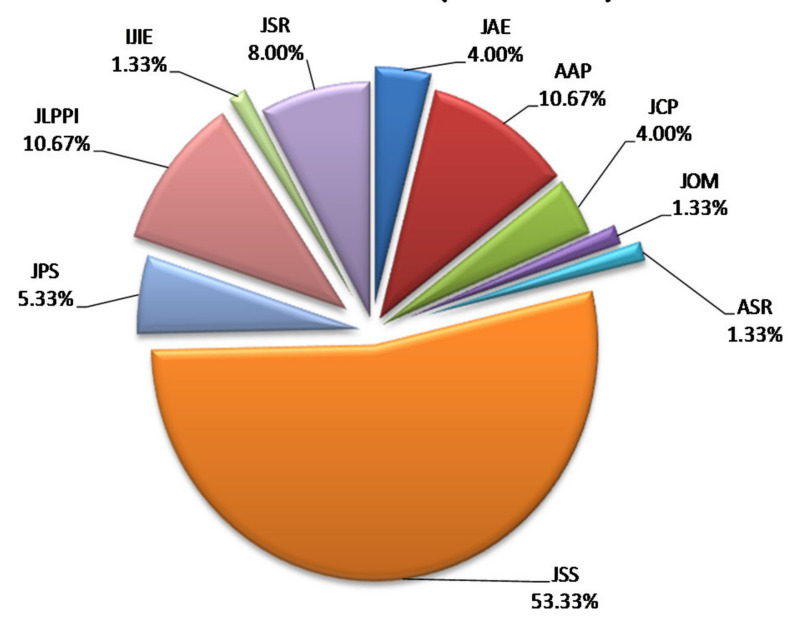

(d)

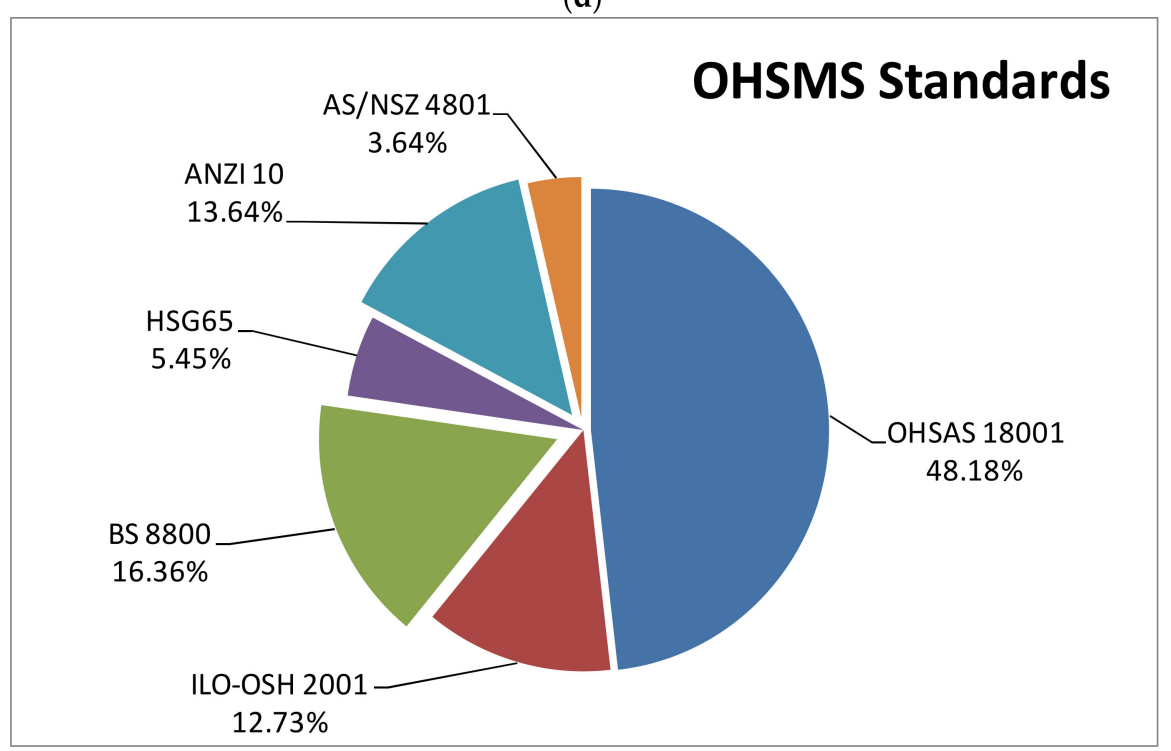

(e)

Figure 1. Cont. 


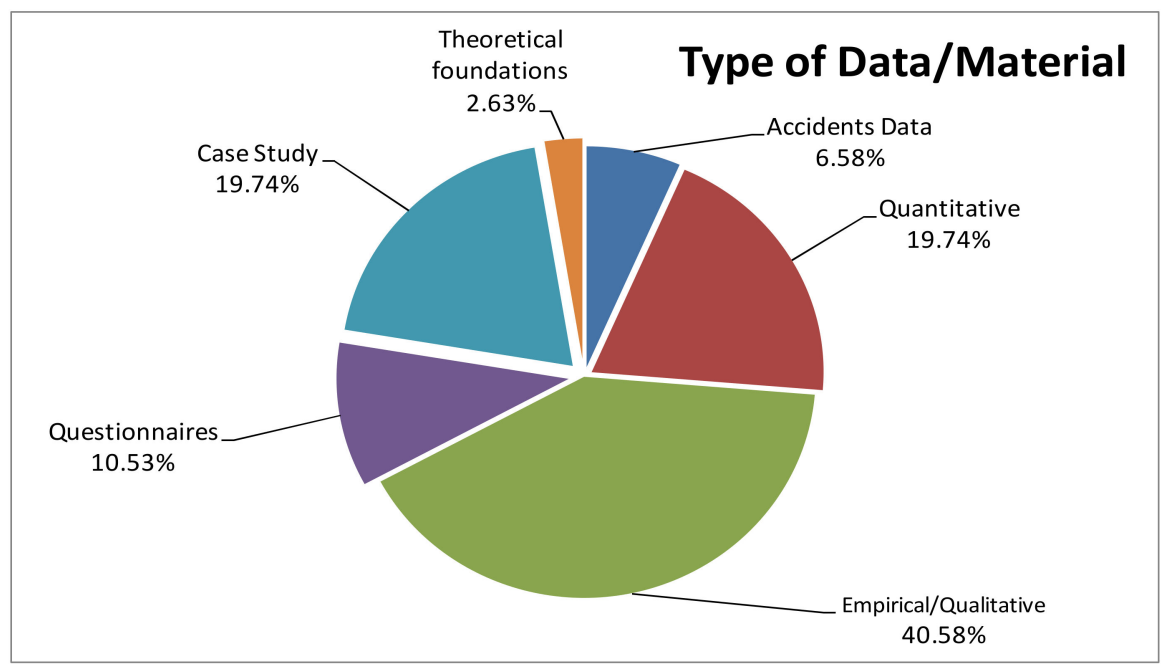

(f)

Figure 1. It depicts for the period of 2006-2017 the various relative occurrence frequencies of papers with OHSMS-standards.

The survey relating to the above 10 journals revealed (according to Appendix B, Table A2) that the papers concerning OHS and including OHSMS standards were very few (i.e., for JAE the maximum percentage is only $0.34 \%$ taking into account the total number $\mathrm{N}$ of the investigated papers and only $\sim 4 \%$ as far as the normalized per journal percentage is concerned), while the majority (i.e., $99.24 \%$ ) is represented by papers without OHSMS standards. Taking into account the graphs of Figure 1, we note that although AAP is the journal with the most publications for 2006-2017 (Figure 1a), JSS is the journal with the greatest number of publications, concerning OHSMS standards (Figure 1b-d).

Besides, the pie-chart of Figure 1e reveals that the OHSAS 18001 standard, presents the higher relative occurrence-frequency $(47.06 \%$ ) in comparison with the other OHSMS standards (of Table A2 in Appendix B), that is, OHSAS 18001 is the most frequent OHSMS standard according to scientific literature review. This can be related with the fact that this international standard was the result of the co-operation of 13 different international organizations which represent $80 \%$ of the certification bodies.

In addition, the graph $1 \mathrm{f}$ which depicts the percentage distribution of the articles (with OHSMS standards) shows that "Empirical/Qualititative" is the most frequent type compared with various types of data.

In Figure 2 we illustrate the yearly variation of the number (nST) of papers with OHSMS standards, published by the previous referred 10 journals, during 2006-2017 (panel a) and the corresponding percentage distribution of papers in association with the year of publication (panel $b$ ). The inserted bar-graph in panel a, depicts the relative occurrence frequency of papers concerning OHS which include OHSMS standards in association with the title of the 10 journals (horizontal axis).

The curve of the graph of Figure 2a shows the existence of a long-term trend factor with positive inclination (throughout the period 2007-2012), with negative inclination (for the period 2013-2015) and also with a positive inclination (throughout the 2016-2017). In particular, there is a gradual increasing for the period 2006-2012 (with a maximum in years 2011 and 2012), while for the years 2013-2015, an abrupt decreasing with an intensive negative slope. The second graph (pie-chart) shows that 2011 and 2012 are the years with the greatest percentage of papers referring to OHSMS systems.

To continue, the pie-chart of Figure 3 displays the distribution of papers with OHSMS standards (published by the 10 journals during 2006-2017) in association with various fields of application (Industrial Sector: 28\%; Construction Sector: 16\%; Chemical Sector: 6.67\%; Oil and Refinery: 4\%; Mining: 4\%; Shipbuilding Sector: $4 \%$; Food Sector: 4\%; Railways Sector: $2.67 \%$; Transportations Sector: $1.33 \%$; Telecommuncations: $1.33 \%$; Other: $28 \%$ ). The major evident feature of this pie-chart is that the field of "Industry" concentrates the maximum number of the papers with OHSMS standards. 
Apparently, one reason is that the industrial organizations present more dangerous working conditions in comparison with other corporations (for example due to the existence of heavy machines in the production procedure) $[9,44]$. Moreover, it is apparent that the construction sector is following, due to the greatest number of occurring incidents.

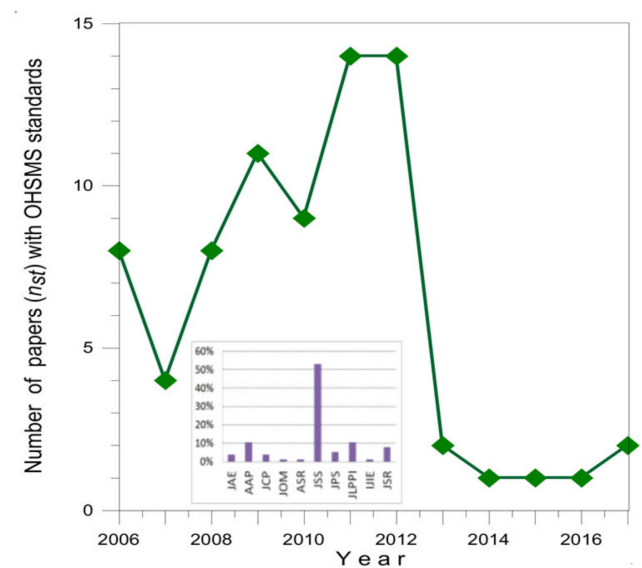

(a)

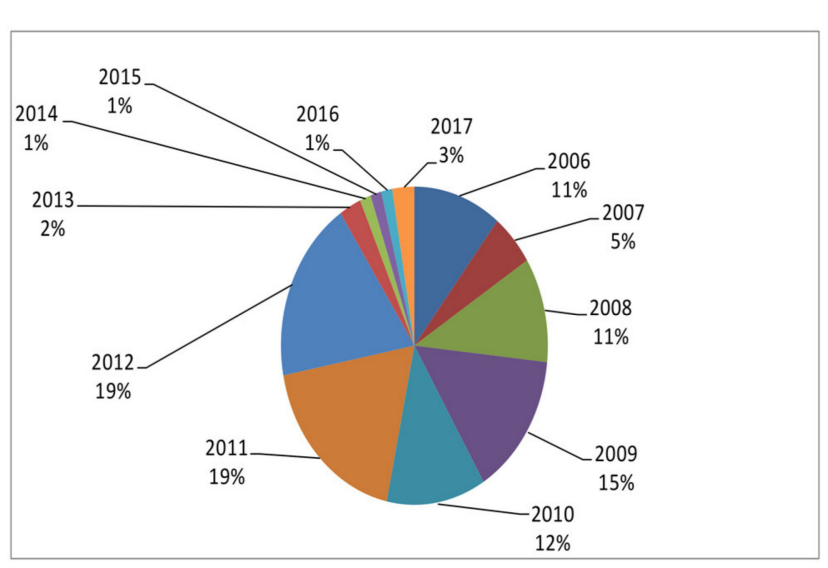

(b)

Figure 2. (a) The curve illustrates the variation of the number of papers with OHSMS standards published by the 10 journals during 2006-2017. (b) Distribution of papers with OHSMS standards in association with the year of publication.

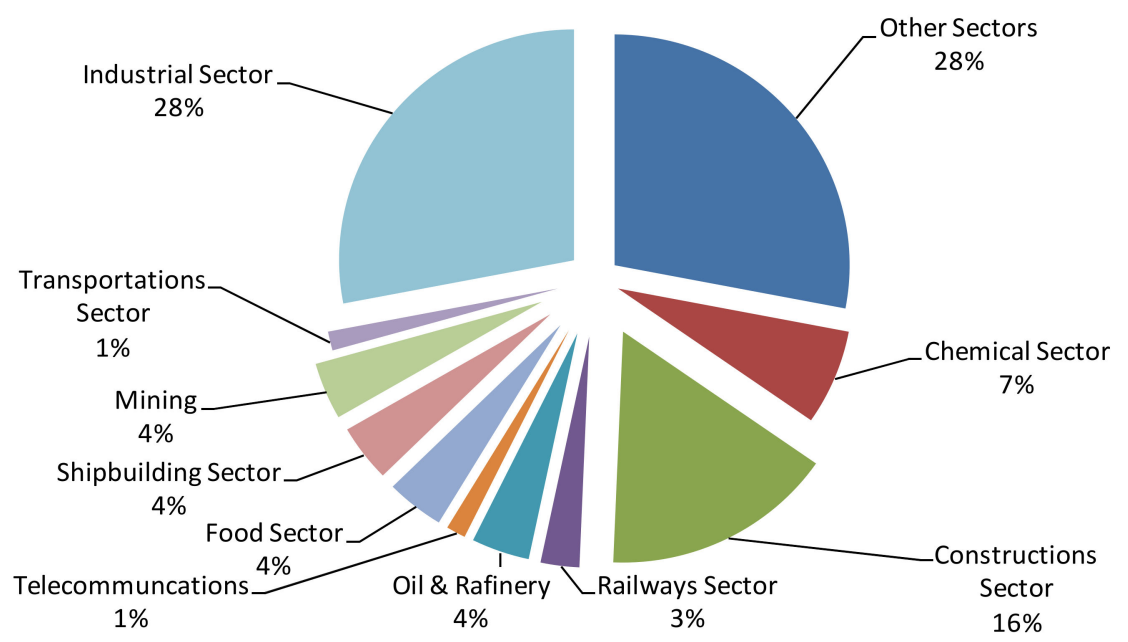

Figure 3. The pie-chart displays the distribution of papers with OHSMS standards (published by the 10 journals during 2006-2017) in association with the various fields of application.

\section{Discussion}

Taking into account that nearly 2.3 million of people die per year due to work-related accidents and/or diseases, occupational injuries and/or illnesses are significantly adverse for the employers and also for the state's economy, resulting in losses from early retirements, the staff absences and the high insurance costs $[45,46]$. Thus, occupational health/safety aspects represent some of the most crucial subjects of the social policy in the EU and as a consequence the Lisbon strategy was adopted for growth and employment, which aims to create jobs with care in health and safety for the employees.

Over the past three decades the use of Occupational Health and Safety Management Systems (OHSMS) has expanded in the workplaces of developed economies and their growing usage could be attributed to many reasons and factors. In particular, OHSMSs embody the principles of "continuous improvement" or "quality management" which have been used and applied by enterprises for improved business competitiveness. Taking into account that the principles of OHSMS are similar to 
methods such as Total Quality Management, it is presumable that experience with TQM has formed a basis for new applications of removing occupational hazards and improving safety awareness [47].

OHSMS differ as far as the miscellaneous techniques of implementation are concerned. According to Frick and Wren [40] there are three types of implementation, that is, voluntary, mandatory and hybrid. The first one exists when companies affiliate OHSMS on their own volition. On the other hand, mandatory systems have been enforced in many European countries (for example in Denmark and Norway) where the state's legislation requires establishment of a RAA system. Quasimandatory methodologies may also exist in case of external commercial requirements which take the form of legislative demands. Thus, many organizations settle OHSMS to comply with the demands of customers and suppliers, principal contractors and other commercial bodies. Hybrid methods require an admixture of voluntary motives and legislative requirements [47]. It is worth noting that, only a fraction of all employers and/or organisations have introduced what it is called as OHS management systems (such as OHSAS 18001) [2]. Yet, within the EU, California (USA) and in many other countries, employers are required by regulation mandated to organise a systematic OHS management (in the EU according to the Framework Directive of 89/391/EEC).

Compliance with these regulations will result in an effective prevention of OHS risks, even without introducing OHSAS or any other voluntary OHS management system. Some other distinctions that should be underlined are the following:

(i) The term "systematic" in mandatory systematic OHSM is not at all the same as the term "system" in voluntary OHSM systems. This means that the UK's HSG 65 is quite different from the other described "systems." HSG 65 constitutes guidelines (best practice) for how to comply with the mandatory regulation of systematic OHSM (transposing of EU directive 89/391/EEC into UK legislation) while all the other listed "systems" are voluntary and more or less commercial products (which still can be very useful).

(ii) Regulated mandatory systematic OHSM is not at all identical to voluntary OHSM standards. This article aims to cover both of them. In any case both mandatory OHSM (such as in all of the EU, since 1989, through 89/391/EEC but also in many other states, for example, in California since 1991) and the much more complex commercial products of voluntary OHSM systems (such as OHSAS 18001) are critically discussed and distinguished.

(iii) The term "Standard" is also a term with importantly different meanings. In Anglo-saxon countries this is often the same as a regulation but a voluntary standard (such as ISO) is (by definition) not a regulation.

The implementation and application of a range of efficient OHS management actions systematically, can contribute to optimal results for all interested parties. Organizations of all types establish a systematic process to manage OHS and develop OHSMS systems within the context of (i) the general growth of concern from all interested parties about OHS, (ii) changes to legislation and (iii) other measures to foster sustained OHS improvement. There are many reasons for organizations to develop OHSMSs (for example legal imperatives, ethical concerns, industrial considerations, financial performance improvement, etc.). Implementation of an efficient OHSMS will create a reduction of workplace illnesses and injuries, minimizing the expenses associated with accidents [28]. Consequently, the application of OHSMS standards provides a unique instrument for the development of a sustainable safety culture within enterprises. Besides, human factors (including the culture, politics, etc.) within organizations can make or break the effectiveness of any management system and needs to be considered very carefully when implementing a management system [22]. An OHSMS standard specifies requirements in order to help any enterprise to formulate a strategy taking into account legislation and information about risks and/or harm. It applies to those hazards over which the organization may exert control and over which it can be expected to have an influence [28]. 
Other standards (like ISO 31000, IEC31010) constitute an introduction to selected techniques and compare their possible applications, benefits and limitations. They also provide references to sources of more detailed information.

With the globalization of the economy and the success of Quality Management Systems (QMS) and of Environmental Management Systems (EMS), organizations require a simple, integrated and also a global management system. For this reason, and due to the lack of a model for an OHS management system that has been accepted worldwide, systems or models, guides or norms of the OHS management, have been propagated throughout the world.

Previous investigations have recognized a research gap, as far as the studies of the reliability and validity of OHSMS standards, are concerned [48]. In this study, the most considerable OHSMS standards created at the international level, are presented and analysed at their updated version. In other words, our article introduces different standardized occupational and safety management systems (guidelines), which are commonly used internationally. In particular, the purpose of this work is to collect important information regarding the use of OHSMS standards by achieving a scientific literature investigation of vicarious journals (published by Elsevier B.V., Taylor \& Francis and the American Society of Safety Engineers) covering the time period of 2006-2017. This is an interesting topic which combines academic papers and practically used standards. Subsequently, the main aims of this exploratory study are: (i) the depiction of commercial and industrial trends, as far as the OHSMS standards are concerned, (ii) the implementation of these standards and (iii) the reinforcement of their application in the worksites of organizations.

It is worth mentioning that, few other systematic literature reviews (like the one of Robson et al. [3]) or narrative reviews (e.g., [40-43]) exist, concentrating on the topic of OHSMS standards and concerning the years before 2006. So this is the reason for conducting our review throughout the years 2006-2017. In addition, the literature overview of Li and Guldenmund [49] has a different aim and describes safety management systems (SMSs) as far as the SMSs models are concerned, that is, accident-related models and organizational models.

The methodological steps of the survey included: (i) research of the literature; (ii) screening the journals with the most important studies on S_OHSMS standards; (iii) selection of relevant studies; (iv) appraisal of the quality of the research evidence in the studies.

The review unveils the following:

- There are only a few publications including OHSMS standards (during 2006-2017), which are referred to a variety of occupational fields (like construction, industry, engineering, transportation, chemistry, oil and refinery, et cetera).

- These papers address techniques that have been emerged in areas such as design/development, quality-control and maintenance, as far as occupational risk assessment is concerned.

- "Safety Science" (SS) and "Journal of Loss Prevention in the Process Industries" (JLPPI) are the scientific journals which published (during 2006-2017) the most scientific papers concerning OHSMS.

- The sector of "Industry" (with 28\%) and also the "Construction" (with 16\%), accounted for the highest percentage, as far as the usage of OHSMS standards is concerned, presumably because their work conditions are more unstable and dangerous in comparison with other occupational sectors (e.g., telecomunications). In addition, these sectors are very hazardous worldwide, owing to their unique dynamic nature, poor conditions and tough environment $[44,50]$.

- The comparison between the previous presented OHSMS standards (in Table 4), depicts an overview of their features, comparatively with various developed evaluation-criteria.

- The OHSAS 18001 standard, presents the higher relative occurrence-frequency $(48 \%)$ in comparison with the other OHSMS standards, due to the fact that this international standard was produced by the co-operation of 13 different international organizations which represent $80 \%$ of the certification bodies. 
- The percentage distribution of the papers (with OHSMS standards) reveals that "Empirical/Qualititative" is the most frequent type compared with other types of data.

- Our selected graphs, show (for the distribution of the publications with OHSMS standards) the existence of a long-term trend factor with positive inclination (during 2007-2012), with negative inclination (during 2013-2015) and also with a positive inclination (throughout the 2016-2017).

- In general, there is an increasing scientific interest for OHSMS standards, especially in period 2009-2012.

- The entire objective of the usage of OHSMS standards is to support and promote efficient OHS practices, in balance with socio-economic requirements [2].

- The OHSMS standards are not legally binding and have not got the intention to replace national laws or regulations and/or accepted standards.

- OHSMS have been proposed as a way to reduce injuries and illnesses for businesses of all types and sizes [51,52].

- The various OHSMS standards have common basic requirements and features but they are implemented in different processes. Besides, the different OHSMS standards follow, in general, similar paths between "start" and "finish."

- Many organizations apply an "integrated" management system which combines the requirements of two or more management system standards simultaneously (for example OHSMS with Environmental, or OHSMS with Quality management systems standards).

\section{Conclusions}

Governments, employers and workers recognize, day after day, the posistive impact of introducing S_OSHMS standards at the organization level, both on the reduction of hazards/risks and also on productivity. In particular the benefits of effective S_OSHMS standards to any commercial body or enterprise include: (i) more effective usage of resources, (ii) improved financial performance, (iii) improved risk management and (iv) increased capability to deliver consistent and improved services and products. OHSMS standards are not intended to replace national laws, regulations or accepted standards but on the other side, their main aim is to support and promote efficient OHS practices, in balance with socio-economic requirements.

Using the previous analysis and its main outcomes, the next dominant conclusions can be extracted:

- The application of OHSMS standards is not significantly extended in organizations and the knowledge about them has not been fully shared and expanded among the miscellaneous scientific fields, so we have the opinion, that the scientific community, have to transfer the similarities from one field to another.

- The implementation of a "integrated" management systems which combine the requirements of two or more management system standards simultaneously (for example OHSMS with Environmental, or OHSMS with Quality management systems standards) would enable organizations to achieve efficient results on the reduction of risks and also on productivity.

- OHSMS standards can be developed and implemented by organizations of any type and any size (large or small).

- As this study is not an empirical research but a review, the value of the article rests on clear distinctions, definitions and analysis. Moreover this exploratory study, provides a rich description for the usage of OHSMS standards in workplaces and lays the background for further research into the reliability and reinforcement of their application in any organization.

As a general conclusion, our literature survey shows that: (i) only a small number of published articles focusing on OHSMS standards (and concerning miscellaneous occupational fields) are available for the period of years 2006-2017 and (ii) the scientific community expanded its interest for the usage of OHSMS standards, during the years of 2009-2012. 
Author Contributions: Conceptualization, P.M., D.K., I.N.; Data curation, P.M., S.T.; Formal analysis, P.M., D.K.; Funding acquisition, I.N.; Investigation, P.M., D.K.; Methodology, P.M., D.K., I.N.; Writing—original draft, P.M.; Writing-review \& editing, P.M., D.K., I.N.

Conflicts of Interest: We declare no conflict of interest.

\section{Abbreviations and Acronyms}

\begin{tabular}{|c|c|}
\hline ANSI & American National Standarization Institute \\
\hline JAE & Applied Ergonomics \\
\hline ASR & Architectural Science Review \\
\hline AENOR & Asociación Española de Normalización/Certificación (Spanish Assoc. for Standards) \\
\hline AS/NZS & Australian/New Zealand Standard \\
\hline BSI & British Standards Institution \\
\hline BSC & British Safety Council \\
\hline CPQRA & Chemical Process Quantitative Risk Analysis \\
\hline CCPS & left for Chemical Process Safety \\
\hline UNI & Ente Nazionale Italiano di Unificazione (Italian National Unification) \\
\hline EMS & Environmental Management Systems \\
\hline HSE & Health and Safety Executive \\
\hline IEC & International Electrotechnical Commission \\
\hline IJIE & International Journal of Industrial Ergonomics \\
\hline ILO & International Labour Organization \\
\hline IMS & International Management Systems \\
\hline ISO & International Organization for Standardization \\
\hline $\mathrm{JCP}$ & Journal of Cleaner Production \\
\hline JLPPI & Journal of Loss Prevention in the Process Industries \\
\hline JOM & Journal of Operations Management \\
\hline JSR & Journal of Safety Research \\
\hline OHSAS & Occupational Health and Safety Assessment Series \\
\hline OHSMS & Occupational health and safety management system \\
\hline OHS & Occupational health-safety \\
\hline JPS & Professional Safety \\
\hline QMS & Quality Management Systems \\
\hline RAA & Risk analysis and assessment \\
\hline JSS & Safety Science \\
\hline SSC & Singapore Standards Council \\
\hline S_OHSMS & Sustainability and Occupational Health and Safety Management Systems \\
\hline TQM & Total Quality Management \\
\hline
\end{tabular}




\section{Appendix A}

Table A1 presents the classification results of 75 papers [3,51,53-125] which are associated with OHSMS standards, covering the period of $2006-2017$.

Table A1. The classification results of the 75 papers.

\begin{tabular}{|c|c|c|c|c|c|c|c|}
\hline $\mathrm{A} / \mathrm{A}$ & Paper Citation & Authors & $\begin{array}{c}\text { Year of } \\
\text { Publication }\end{array}$ & OHSMS Standard & $\begin{array}{l}\text { Type of Paper Data or } \\
\text { Material }\end{array}$ & Field of Application & Source \\
\hline (A) & (B) & (C) & (D) & (E) & (F) & (G) & (H) \\
\hline 1 & [53] & $\begin{array}{l}\text { Jørgensen T.H. Arne Remmen M. } \\
\text { Dolores Mellado }\end{array}$ & 2006 & ISO 14001; OHSAS 18001 & Empirical/Qualitative & All Sectors & JCP \\
\hline 2 & [54] & J.R. Santos-Reyes and \& Beard, A. N. & 2006 & BS 8800 & Empirical/Qualitative & All Sectors & JPS \\
\hline 3 & [55] & Adele Abrahms & 2006 & ANZI Z10-2005 & Empirical/Qualitative & All Sectors & JPS \\
\hline 4 & [56] & Manuele, Fred & 2006 & ANZI Z10-2005 & Empirical/Qualitative & All Sectors & JPS \\
\hline 5 & [57] & Wrona & 2006 & ANSI Z16.2 & Empirical/Qualitative & All Sectors & JSR \\
\hline 6 & [58] & Nielsen et al. & 2006 & OHSAS 18001 & Empirical/Qualitative & Industrial sector & JSR \\
\hline 7 & [59] & Cadieux et al. & 2006 & OHSAS 18001 & Empirical/Qualitative & Industrial sector & JSR \\
\hline 8 & [60] & Paivinen & 2006 & BS 8800 & Empirical/Qualitative & Telecommunications & IJIE \\
\hline 9 & [61] & S.X. Zeng, Jonathan J., Shi G.X. Lou & 2007 & OHSAS 18001 & Questionnaires & All Sectors & JCP \\
\hline 10 & [62] & Fernandez-Muniz et al. & 2007 & BS 8800, OHSAS 18001 & Empirical/Qualitative & Industrial sector & JLPPI \\
\hline 11 & [63] & Coleman and Kerkering & 2007 & ANSI Z16.1-1967 & Accidents Data & Mining & JSR \\
\hline 12 & [3] & Robson et al. & 2007 & ANSI Z10, OHSAS 18001, BS8800, HSG 65 & Quantitative & All Sectors & JSS \\
\hline 13 & [64] & Bevilacqua et al. & 2008 & OHSAS 18001 & Quantitative & Oil \& Refinery & AAP \\
\hline 14 & [65] & Brooks & 2008 & ANSI Z10 & Quantitative & All Sectors & JSS \\
\hline 15 & {$[66]$} & Duijm et al. & 2008 & BS 8800, OHSAS 18000, ILO-OSH 2001, HSG 65 & Questionnaires & Industrial sector & JSS \\
\hline 16 & [67] & Lind, Kivisto-Rahnasto & 2008 & BS 8800, ILO-OSH:2001, OHSAS 18001 & Case Study & Transportations Sector & JSS \\
\hline 17 & {$[68]$} & $\begin{array}{l}\text { Nielsen et al. } \\
\text { Nolo }\end{array}$ & 2008 & OHSAS 18001 & Quantitative & Industrial sector & JSS \\
\hline 18 & [69] & Schrover & 2008 & ISO-9001, ISO-14001, OHSAS-18001 & Theoretical Foundations & Chemical Sector & JSS \\
\hline 19 & [70] & Zeng et al. & 2008 & OHSAS 18001, ISO 9001 & Accidents Data & Construction Sector & JSS \\
\hline 20 & [71] & Komljenovic et al. & 2008 & $\begin{array}{l}\text { AS/NZS: 1999, CAN/CSA Q850-97: 2002. ISO, } \\
\text { 1999, 2000, ANSI: 2000, ASTME2205-02, 2002 }\end{array}$ & Accidents Data & Mining & JSS \\
\hline 21 & [72] & Caroly et al. & 2009 & OHSAS 18001 & Empirical/Qualitative & Chemical Sector & JAE \\
\hline 22 & {$[73]$} & Chang and Liang & 2009 & OHSAS 18001 ILO-OSH-2001 BS 8800 . HSG 65 & Empirical/Oualitative & Chemical Sector & JLPPI \\
\hline 23 & [74] & Santos-Reves, Beard & 2009 & BS 8800 ILO-OSH: 2001 HSG 65 & Empirical/Oualitative & Oil \& Refinery & ILPPI \\
\hline 24 & [75] & Crippa et al. & 2009 & OHSAS 18001 & Quantitative & Oil \& Refinery & JLPPI \\
\hline 25 & [76] & Knegtering, Pasman, & 2009 & OHSAS 18001 & Empirical/Qualitative & Industrial sector & JLPPI \\
\hline 26 & [77] & Pasman et al. & 2009 & OHSAS 18001 & Empirical/Qualitative & Industrial sector & JLPPI \\
\hline 27 & [78] & Moriyama, Ohtani & 2009 & ILO-OSH 2001, BS 8800 & Empirical/Qualitative & Food Sector & JSS \\
\hline 28 & [79] & Fernandez-Muniz et al. & 2009 & BS 8800 OHSAS 18001 & Questionnaires & All Sectors & ISS \\
\hline 29 & [80] & Celik M. & 2009 & OHSAS 18001:2007 & Quantitative & Shipbuilding Sector & JSS \\
\hline 30 & [81] & Reniers et al. & 2009 & OHSAS 18000 & Empirical/Qualitative & All Sectors & JSS \\
\hline 31 & [82] & Baram & 2009 & ILO-OSH 2001 & Empirical/Qualitative & Industrial sector & JSS \\
\hline 32 & [83] & Shengli Niu, & 2010 & ILO-OSH 2001 & Empirical/Qualitative & All Sectors & JAE \\
\hline 33 & [84] & Gangolells et al. & 2010 & OHSAS 18001 & Quantitative & Construction Sector & JSR \\
\hline 34 & [85] & Cheng et al. & 2010 & ANSI Z10 & Quantitative & Construction Sector & JSS \\
\hline 35 & [86] & Jacinto, Silva & 2010 & BS 8800 & Case Study & Shipbuilding Sector & JSS \\
\hline 36 & [87] & Sgourou et al. & 2010 & BS 8800 & Quantitative & All Sectors & JSS \\
\hline
\end{tabular}


Table A1. Cont.

\begin{tabular}{|c|c|c|c|c|c|c|c|}
\hline $\mathbf{A} / \mathbf{A}$ & Paper Citation & Authors & $\begin{array}{c}\text { Year of } \\
\text { Publication }\end{array}$ & OHSMS Standard & $\begin{array}{c}\text { Type of Paper Data or } \\
\text { Material }\end{array}$ & Field of Application & Source \\
\hline (A) & (B) & (C) & (D) & (E) & (F) & (G) & (H) \\
\hline 37 & [88] & Fera, Macchiaroli & 2010 & OSHAS 18001 & Case Study & All Sectors & JSS \\
\hline 38 & [89] & Lindhout et al. & 2010 & OHSAS 18001 & Empirical/Qualitative & Chemical Sector & JSS \\
\hline 39 & [90] & Celik M. & 2010 & ISO 9001:2000, ISO 14001:2004, OHSAS 18001:2007 & Case Study & Shipbuilding sector & JSS \\
\hline 40 & [91] & Dawson et al. & 2011 & $\mathrm{AS} / \mathrm{NZ} 4360$ & Empirical/Qualitative & All Sectors & AAP \\
\hline 41 & [92] & Low Sui Phen \& Goh Kim Kwang & 2011 & ISO 14001; OHSAS 18001 & Questionnaires & Construction Sector & ASR \\
\hline 42 & [93] & Jallon et al. & 2011 & OHSAS 18001 & Quantitative & Industrial sector & JSR \\
\hline 43 & [94] & Leka et al. & 2011 & ILO-OSH 2001, BS OHSAS and ANSI Z-10 & Empirical/Qualitative & Construction Sector & JSS \\
\hline 44 & [95] & Blewett, O'Keeffe & 2011 & ANSI Z10, OHSAS 18001 & Quantitative & Food Sector & JSS \\
\hline 45 & [96] & Vinodkumar, Bhasi & 2011 & OHSAS 18001, BS 8800 & Questionnaires & Chemical Sector & JSS \\
\hline 46 & [97] & Hohnen, Hasle & 2011 & OHSAS 18001 & Case Study & All Sectors & JSS \\
\hline 47 & [98] & $\mathrm{Lu}, \mathrm{Li}$ & 2011 & OHSAS 18001 & Case Study & Mining & JSS \\
\hline 48 & [99] & Zwetsloot et al. & 2011 & OHSAS 18001 & Case Study & Industrial sector & JSS \\
\hline 49 & [100] & Frick & 2011 & $\begin{array}{l}\text { ANSI Z-10, (2005), Australia and New Zealand } \\
\text { (AS/NZS 4804), The Netherlands (NPR 5001), } \\
\text { Spain (UNE 81900), UK (BS 8800), ISO 9000, ISO } \\
\text { 14000, OHSAS:18001, ILO-OSH } 2001\end{array}$ & Theoretical Foundations & Industrial sector & JSS \\
\hline 50 & [101] & Granerud, Rocha & 2011 & OHSAS 18001, ISO 14000, ISO 9000 & Case Study & Industrial sector & JSS \\
\hline 51 & [102] & Kristensen & 2011 & ISO 14001, OHSAS 18001 & Case Study & Industrial sector & JSS \\
\hline 52 & [103] & Zwetsloot et al. & 2011 & ISO 9000, ISO 14000, OHSAS 18000 series & Case Study & Industrial sector & JSS \\
\hline 53 & [104] & Hasle Peter, Gerard Zwetsloot & 2011 & OHSAS 18001 & $\begin{array}{l}\text { Quantitative, } \\
\text { Empirical/Qualitative }\end{array}$ & Industrial Sector & JSS \\
\hline 54 & [105] & $\begin{array}{c}\text { Beatriz Fernández-Muñiz, José } \\
\text { Manuel Montes-Peón,", Camilo José } \\
\text { Vázquez-Ordás }\end{array}$ & 2012 & OHSAS 18001 & Empirical/Qualitative & All Sectors & AAP \\
\hline 55 & [106] & Goh, Y.M. et al. & 2012 & AS/NZS 4801 & Empirical/Qualitative & Construction Sector & AAP \\
\hline 56 & [107] & Cheng et al. & 2012 & ANSI Z.16.2-1995, ILO Guidelines & Quantitative & Construction Sector & AAP \\
\hline 57 & [108] & Pinto et al. & 2012 & BS 8800:2004 & Quantitative & Construction Sector & AAP \\
\hline 58 & [109] & Badri et al. & 2012 & OHSAS 18000 & Case Study & Industrial sector & AAP \\
\hline 59 & [110] & $\begin{array}{l}\text { Luria Gil, Ido Morag } \\
\text { Beatriz Fernández Muñiz José }\end{array}$ & 2012 & OHSAS 18001 & Empirical/Qualitative & All Sectors & AAP \\
\hline 60 & [111] & $\begin{array}{c}\text { Manuel Montes-Peón Camilo José } \\
\text { Vázquez-Ordás }\end{array}$ & 2012 & OHSAS 18001 & Questionnaires & All Sectors & JCP \\
\hline 61 & [112] & Jeremy Mawhood \& Claire Dickinson & 2012 & HSG 65 & Empirical/Qualitative & Railways Sector & JPS \\
\hline 62 & [113] & Lee et al. & 2012 & BS 8800, OHSAS 18001, ILO-OSH 2001 & Accidents data & All Sectors & JLPPI \\
\hline 63 & [114] & Gnoni, Lettera & 2012 & OHSAS 18001 & Empirical/Qualitative & Industrial sector & JLPPI \\
\hline 64 & [115] & Badri et al. & 2012 & ANSI Z10 & Empirical/Qualitative & Industrial sector & JSS \\
\hline 65 & [116] & Hamidi et al. & 2012 & OHSAS-18001, ANSI z10 & Case Study & Construction Sector & JSS \\
\hline 66 & [117] & Hsu et al. & 2012 & OHSAS: 18001, BS 8800,ILOOSH 2001 & Quantitative & Food Sector & JSS \\
\hline 67 & [118] & Wang, Liu & 2012 & OHSAS 18001, ILO-OSH 2001, HSG 65 & Questionnaires & Railways Sector & JSS \\
\hline 68 & [119] & Ismail et al. & 2012 & OHSAS 18001 & Empirical/Qualitative & Construction Sector & JSS \\
\hline 69 & [120] & $\begin{array}{l}\text { Jesús Abad, Esteban Lafuente, Jordi } \\
\text { Vilajosana }\end{array}$ & 2013 & OHSAS 18001 & Accidents data & All Sectors & JSS \\
\hline 70 & [121] & Santos G. et al. & 2013 & OHSAS 18001 & Questionnaires & Industrial Sector & JSS \\
\hline
\end{tabular}


Table A1. Cont.

\begin{tabular}{|c|c|c|c|c|c|c|c|}
\hline $\mathbf{A} / \mathbf{A}$ & Paper Citation & Authors & $\begin{array}{c}\text { Year of } \\
\text { Publication }\end{array}$ & OHSMS Standard & $\begin{array}{c}\text { Type of Paper Data or } \\
\text { Material }\end{array}$ & Field of Application & Source \\
\hline (A) & (B) & (C) & (D) & (E) & (F) & (G) & (H) \\
\hline 71 & [122] & $\begin{array}{l}\text { Chris K.Y. Lo, Mark Pagell, Di Fan, } \\
\text { Frank Wiengarten, Andy C.L. Yeung }\end{array}$ & 2014 & OHSAS 18001 & Case Study & Construction Sector & JOM \\
\hline 72 & [123] & Yazdani A. et al. & 2015 & OHSAS18001, BS 8800:2004 & Empirical/Qualitative & Industrial Sector & JAE \\
\hline 73 & [51] & Autenrieth D.A. et al. & 2016 & OHSAS 18001, ANZI 10 & Case Study & Industrial Sector & JSS \\
\hline 74 & [124] & Miskeen Ali Gopang, et al. & 2017 & ILO-OSH 2001 & Empirical/Qualitative & Other Sectors & JSS \\
\hline 75 & [125] & Segarra Cañamares M. et al. & 2017 & OHSAS 18001 & Case Study & Construction Sector & JSS \\
\hline
\end{tabular}

\section{Appendix B}

Table A2 presents statistical results of ten (10) journals investigation, concerning articles with OHSMS standards (during 2006-2017).

Table A2. Statistical results of ten (10) journals investigation, concerning articles with OHSMS.

\begin{tabular}{|c|c|c|c|c|c|c|c|c|}
\hline $\mathrm{Nr}$ & Journal & Acronym & $\begin{array}{c}\text { Number of } \\
\text { Investigated } \\
\text { Papers } \\
\text { (Absolute } \\
\text { Frequency Ni) }\end{array}$ & $\begin{array}{c}\text { Relative } \\
\text { Frequency } \\
(\mathrm{Fi}=\mathrm{Ni} / \mathrm{N})(\%)\end{array}$ & $\begin{array}{l}\text { Number of Papers } \\
\text { Concerning OHS } \\
\text { Which Include or } \\
\text { Use OHSMS } \\
\text { Standards }\left(\mathrm{n}_{\mathrm{ST}(\mathrm{i})}\right)\end{array}$ & $\begin{array}{c}\text { Relative Occurrence } \\
\text { Frequency of Papers } \\
\text { (Referred to N) Which } \\
\text { Include OHSMS-Standards } \\
\left(\mathrm{f}_{\mathrm{ST}(\mathrm{i})}=\mathrm{n}_{\mathrm{ST}(\mathrm{i})} / \mathrm{N}\right)(\%)\end{array}$ & $\begin{array}{c}\text { Normalized (Per Journal) } \\
\text { Occurrence Frequency of } \\
\text { Papers Which Include } \\
\text { OHSMS Standards } \\
\left(\mathrm{f}_{\mathrm{i}}^{*}=\mathrm{n}_{\mathrm{ST}(\mathrm{i})} / \mathrm{N}_{\mathrm{i}}\right)(\%)\end{array}$ & $\begin{array}{c}\text { Relative Occurrence } \\
\text { Frequency of Papers } \\
\text { (Referred to S) Which } \\
\text { Include OHSMS Standards } \\
\left(f^{*}{ }^{*}(i)=n_{S T(i)} / S\right)(\%)\end{array}$ \\
\hline & (A) & (B) & (C) & $(D)=(C) / N$ & (E) & $(F)=(E) / N$ & $(G)=(E) /(C)$ & $(H)=(E) / S$ \\
\hline 1 & Applied Ergonomics & JAE & 886 & $9.02 \%$ & 3 & $0.03 \%$ & $0.34 \%$ & $4.00 \%$ \\
\hline 2 & $\begin{array}{l}\text { Accident Analysis and } \\
\text { Prevention }\end{array}$ & AAP & 1522 & $15.50 \%$ & 8 & $0.08 \%$ & $0.53 \%$ & $10.67 \%$ \\
\hline 3 & Journal of Cleaner Production & JCP & 1005 & $10.23 \%$ & 3 & $0.03 \%$ & $0.30 \%$ & $4.00 \%$ \\
\hline 4 & $\begin{array}{l}\text { Journal of Operations } \\
\text { Management }\end{array}$ & JOM & 995 & $10.13 \%$ & 1 & $0.01 \%$ & $0.10 \%$ & $1.33 \%$ \\
\hline 5 & Architectural Science Review & ASR & 1007 & $10.25 \%$ & 1 & $0.01 \%$ & $0.10 \%$ & $1.33 \%$ \\
\hline 6 & Safety Science & JSS & 945 & $9.62 \%$ & 40 & $0.41 \%$ & $4.23 \%$ & $53.33 \%$ \\
\hline 7 & Professional Safety & JPS & 998 & $10.16 \%$ & 4 & $0.04 \%$ & $0.40 \%$ & $5.33 \%$ \\
\hline 8 & $\begin{array}{l}\text { Journal of Loss Prevention in } \\
\text { the Process Industries }\end{array}$ & JLPPI & 881 & $8.97 \%$ & 8 & $0.08 \%$ & $0.91 \%$ & $10.67 \%$ \\
\hline 9 & $\begin{array}{l}\text { International Journal of } \\
\text { Industrial Ergonomics }\end{array}$ & IJIE & 955 & $9.72 \%$ & 1 & $0.01 \%$ & $0.10 \%$ & $1.33 \%$ \\
\hline 10 & Journal of Safety Research & JSR & 628 & $6.39 \%$ & 6 & $0.06 \%$ & $0.96 \%$ & $8.00 \%$ \\
\hline & Totals: & & 9822 & $100.00 \%$ & 75 & $0.76 \%$ & $7.96 \%$ & $100.00 \%$ \\
\hline
\end{tabular}

Annotations: The entire (total) absolute frequency (i.e., the total number of investigated articles) is: $\mathrm{N}=9822$; The number of articles that concern OHSS and include (or use or refer to)

OHSMS standards is: $\mathrm{S}=75$ 


\section{References}

1. Loke, Y.; Tan Wee, J.; Pegy, H. Economic Cost of Work-Related Injuries and Health in Singapore; WSH Institute Report; WSH: Singapore, 2013; pp. 1-29. Available online: https://www.wsh-institute.sg/ /media/wshi/ past $\% 20$ publications / 2013/economic $\% 20$ cost $\% 20$ of $\% 20$ work-related\%20injuries $\% 20$ and $\% 20$ ill-health\% 20in\%20singapore.pdf?la=en (accessed on 8 October 2018).

2. Occupational Health and Safety Assessment Series (OHSAS) Project Group. OHSAS 18001:2007Occupational Health and Safety Management Systems_Requirements; OHSAS: Sydney, Australia, 2007; ISBN 978 0580508028 .

3. Robson, L.S.; Clarke, J.A.; Cullen, K.L.; Amber, B.; Colette, S.; Bigelow, P.L.; Irvin, E.; Culyer, A.; Quenby, M. The effectiveness of occupational health and safety management system interventions: A systematic review. Saf. Sci. 2007, 45, 329-353. [CrossRef]

4. Sinelnikov, S.; Inouye, J.; Kerper, S. Using leading indicators to measure occupational health and safety performance. Saf. Sci. 2015, 72, 240-248. [CrossRef]

5. Høj, N.P.; Kröger, W. Risk analyses of transportation on road and railway from a European Perspective. Saf. Sci. 2002, 40, 337-357.

6. Woodruff, J.M. Consequence and likelihood in risk estimation: A matter of balance in UK health and safety risk assessment practice. Saf. Sci. 2005, 43, 345-353. [CrossRef]

7. Reniers, G.L.L.; Dullaert, W.; Ale, B.J.M.; Soudan, K. Developing an external domino accident prevention framework: Hazwim. J. Loss Prev. Process Ind. 2005, 18, 127-138. [CrossRef]

8. Haimes, Y.Y. Risk Modeling, Assessment, and Management, 3rd ed.; John Wiley \& Sons Inc.: New York, NY, USA, 2009; pp. 154-196.

9. Marhavilas, P.K. Risk Assessment Techniques in the Worksites of Occupational Health-Safety Systems with Emphasis on Industries and Constructions. Ph.D. Thesis, Department of Production and Management Engineering, Democritus University of Thrace, Xanthi, Greece, March 2015.

10. Cliff, D. The Management of Occupational Health and Safety in the Australian Mining Industry; International Mining for Development Centre, Mining for Development, Guide to Australian Practice: Melbourne, Australia, 2012; pp. 100-200.

11. International Labour Organization (ILO). Occupational Safety and Health: Synergies between Security and Productivity; ILO's Governing Body Paper GB.295/ESP/3, GB; ILO: Geneva, Switzerland, 2006.

12. ISO/IEC. Guide 51: Safety Aspects-Guidelines for Their Inclusion in Standards, 2nd ed.; ISO/IEC: Geneva, Switzerland, 1999.

13. Lee, M. How Does Climate Change Affect the Assessment of Landslide Risk? 2006. Available online: http:/ / cliffs.lboro.ac.uk/downloads/ML2006.pdf (accessed on 15 July 2017).

14. Olsson, F. Tolerable Fire Risk Criteria for Hospitals; Report 3101; Department of Fire Safety Engineering, Lund University: Lund, Sweden, 1999; ISSN 1402-3504.

15. IEC (International Electrotechnical Commission). Risk Analysis of Technological Systems; International Standard 60300-3-9, Dependability Management-Part 3: Application Guide-Section 9; IEC: Geneva, Switzerland, 1995.

16. Marhavilas, P.K.; Koulouriotis, D.E.; Gemeni, V. Risk Analysis and Assessment Methodologies in the Work Sites: On a Review, Classification and Comparative Study of the Scientific Literature of the Period 2000-2009. J. Loss Prev. Process Ind. 2011, 24, 477-523. [CrossRef]

17. Jonkman, S.N.; van Gelder, P.H.A.J.M.; Vrijling, J.K. An overview of quantitative risk measures for loss of life and economic damage. J. Hazard. Mater. 2003, 99, 1-30.

18. Vrouwenvelder, A.C.W.M.; Lovegrove, R.; Holicky, M.; Tanner, P.; Canisius, G. Risk Assessment and Risk Communication in Civil Engineering, 1st ed.; CIB General Secretariat: Rotterdam, The Netherlands, 2001; pp. 1-62. ISBN 90-6363-026-3.

19. CCPS. Guidelines for Chemical Process Quantitative Risk Analysis, 2nd ed.; Center for Chemical Process Safety (CCPS) of American Institute of Chemical Engineers: New York, NY, USA, 1989; pp. 1-748. ISBN 978-0-8169-0720-5.

20. International Organization for Standardization (ISO). Standards in Action. 2017. Available online: https: / / www.iso.org/standards-in-action.html (accessed on 15 July 2017). 
21. Gallagher, C. Occupational Health and Safety Management Systems: System Types and Effectiveness. Ph.D. Thesis, Deakin University, Melbourne, Australia, 2000.

22. British Standards Institution (BSI). BS 8800:1996-Guide to Occupational Health and Safety Management Systems; BSI: London, UK, 1996; pp. 1-70. ISBN 0-580-25859-9.

23. British Standards Institution (BSI). BS 18004:2008 — Guide to Achieving Effective Occupational Health and Safety Performance; BSI: London, UK, 2008; pp. 1-78. ISBN 9780580529108.

24. British Standards Institution (BSI). BS 8800:2004-Occupational Health and Safety Management Systems-Guide; BSI: London, UK, 2004; pp. 1-87. ISBN 0580439879.

25. Health and Safety Executive (HSE). Successful Health and Safety Management; HSE: London, UK, 1997; pp. 1-80. ISBN 978-0-7176-1276-5.

26. Health and Safety Executive (HSE). Managing for Health and Safety; HSE: London, UK, 2013; pp. 1-66. ISBN 978-0-7176-6456-6.

27. International Labour Organization (ILO). Guidelines on Occupational Safety and Health Management Systems-ILO-OSH 2001; ILO: London, UK, 2009; ISBN 92-2-111634-4.

28. Australian/New Zealand Standard (AS/NZS). AS/NZS 4801:2001-Occupational Health and Safety Management Systems-Specification with Guidance for Use; AS/NZS: Melbourne, Australia, 2001; ISBN 0-7337-4092-8.

29. American Industrial Hygiene Association (AIHA). ANSI/AIHA Z10-2005 Occupational Health and Safety Management Systems; AIHA: New York, NY, USA, 2005; ISBN1 10:1931504644. ISBN2 13:978-1931504645.

30. SAI Global. ANSI/AIHA Z10-2005. Available online: https://www.saiglobal.com/assurance/ohs/Z10.htm (accessed on 15 July 2017).

31. Singapore Standards Council (SSC). SS 506-Occupational Safety and Health (OSH) Management Systems-Part 1: Requirements; SSC: Singapore, 2009; ISBN 978-981-4278-15-7.

32. Singapore Standards Council (SSC). SS 506-Occupational Safety and Health (OSH) Management Systems-Part 2: Guidelines for the Implementation of SS 506: Part 1; SSC: Singapore, 2009; ISBN 978-981-4278-16-4.

33. Romero, J.C.R. Security Management Systems and Health at Work-Certified Or UNS Certified? ILO GuIdelines OHSAS 18001 Standard; Industrial Security of the E.T.S.I.I. Malaga University: Malaga, Spain, 2001; pp. 4-13.

34. Barone, D.; Milano, Italy. Le nuove norme UNI 10617-2012 e UNI 10616-2012 relative ai Sistemi di Gestione della Sicurezza negli impianti a rischio di incidente rilevante. Personal communication, 2012.

35. International Organization for Standardization (ISO). ISO Survey. Available online: https://www.iso.org/ the-iso-survey.html (accessed on 19 September 2018).

36. International Organization for Standardization (ISO). ISO 45001 Occupational Health and Safety-Briefing Notes. 2015. Available online: https://www.iso.org/iso-45001-occupational-health-and-safety.html (accessed on 19 September 2018).

37. International Organization for Standardization (ISO). ISO 45001-Occupational Health and Safety. Available online: https://www.iso.org/iso-45001-occupational-health-and-safety.html (accessed on 19 September 2018).

38. Gallagher, C. Health and Safety Management Systems: An Analysis of System Types and Effectiveness; National Key Centre in Industrial Relations, Monash University: Melbourne, Austrialia, 1997.

39. European Commission. Communication from the Commission Concerning Corporate Social Responsibility: A Business Contribution to Sustainable Development. 2002. Available online: https:/ / eur-lex.europa.eu/ LexUriServ / LexUriServ.do? uri=COM:2002:0347:FIN:EN:PDF (accessed on 26 September 2018).

40. Frick, K.; Wren, J. Reviewing occupational health and safety management: Multiple roots, diverse perspectives and ambiguous outcomes. In Systematic Occupational Health and Safety Management: Perspectives on an International Development; Frick, K., Jensen, P.L., Quinlan, M., Wilthagen, T., Eds.; Pergamon: Amsterdam, The Netherlands, 2000; pp. 17-42. ISBN 9780080434131.

41. Walters, D. (Ed.) Regulating Health and Safety Management in the European Union: A Study of the Dynamics of Change; Presses Interuniversitaires Europeenes: Brussels, Belgium, 2002; ISBN 90-5201-998-3. [CrossRef]

42. Gallagher, C.; Underhill, E.; Rimmer, M. Occupational safety and health management systems in Australia: Barriers to success. Policy Pract. Health Saf. 2003, 1, 67-81. [CrossRef]

43. Saksvik, P.O.; Quinlan, M. Regulating systematic occupational health and safety management: Comparing the Norwegian and Australian experience. Relat. Ind./Ind. Relat. 2003, 58, 33-59. [CrossRef] 
44. Marhavilas, P.K.; Koulouriotis, D.E.; Spartalis, S.H. Harmonic Analysis of Occupational-Accident Time-Series as a Part of the Quantified Risk Evaluation in Worksites: Application on Electric Power Industry and Construction Sector. Reliab. Eng. Syst. Saf. 2013, 112, 8-25. [CrossRef]

45. International Labour Organization (ILO). Emerging Risks and New Patterns of Prevention in Changing World of Work, 1st ed.; ILO: Geneva, Switzerland, 2010; pp. 1-22, ISBN 978-92-2-123342-8 (print), ISBN 978-92-2-123343-5 (web pdf).

46. Jordan, J.R.; Letti, G.; Pinto, T.L. A proposal for the use of serious games in occupational safety. In Occupational Safety and Hygiene II; Arezes, P., Baptista, J.S., Barroso, M.P., Carneiro, P., Cordeiro, P., Costa, N., Melo, R.B., Miguel, S.A., Perestrelo, G., Eds.; Taylor and Francis Group: London, UK, 2014; ISBN 978-1-138-00144-2.

47. Gallagher, C.; Underhill, E.; Rimmer, M. Occupational Health and Safety Management Systems: A Review of their Effectiveness in Securing Healthy and Safe Workplaces; National Occupational Health and Safety Commission: Sydney, Australia, 2001; ISBN 0642709815.

48. Robson, L.S.; Macdonald, S.; Gray, G.C.; Van Eerd, D.L.; Bigelow, P.L. A descriptive study of the OHS management auditing methods used by public sector organizations conducting audits of workplaces: Implications for audit reliability and validity. Saf. Sci. 2012, 50, 181-189. [CrossRef]

49. Li, Y.; Guldenmund, F.W. Safety management systems: A broad overview of the literature. Saf. Sci. 2018, 103, 94-123. [CrossRef]

50. Aneziris, O.N.; Topali, E.; Papazoglou, I.A. Occupational risk of building construction. Reliab. Eng. Syst. Saf. 2012, 105, 36-46. [CrossRef]

51. Autenrieth, D.A.; Brazile, W.J.; Sandfort, D.R.; Douphrate, D.I.; Román-Muñiz, I.N.; Reynolds, S.J. The associations between occupational health and safety management system programming level and prior injury and illness rates in the U.S. dairy industry. Saf. Sci. 2016, 84, 108-116. [CrossRef]

52. Tsalis, T.A.; Stylianou, M.S.; Nikolaou, I.E. Evaluating the quality of corporate social responsibility reports: The case of occupational health and safety disclosures. Saf. Sci. 2018, 109, 313-323. [CrossRef]

53. Jørgensen, T.H.; Remmen, A.; Mellado, M.D. Integrated management systems-Three different levels of integration. J. Clean. Prod. 2006, 14, 713-722. [CrossRef]

54. Santos-Reyes, J.; Beard, A.N. Viability of a systemic safety management system. In Proceedings of the Safety and Reliability Conference, ESREL-2006, Estoril, Portugal, 18-22 September 2006.

55. Adele, A.L. Legal Perpspectives of ANZI Z10-2005. Prof. Saf. 2006, 41-43. Available online: www.xprolegal. com/expertarticles/359-1312558749_ASSE\%20Z10\%20Article.pdf (accessed on 26 September 2018).

56. Fred, M. ANSI/AIHA Z10-2005: The new benchmark for safety management systems. Prof. Saf. 2006, 51, 25-33. Available online: https:/ / aeasseincludes.assp.org/professionalsafety / pastissues/051/02/020206as. pdf (accessed on 26 September 2018).

57. Wrona, R.M. The use of state workers' compensation administrative data to identify injury scenarios and quantify costs of work-related traumatic brain injuries. J. Saf. Res. 2006, 37, 75-81. [CrossRef] [PubMed]

58. Nielsen, K.J.; Carstensen, O.; Rasmussen, K. The prevention of occupational injuries in two industrial plants using an incident reporting scheme. J. Saf. Res. 2006, 37, 479-486. [CrossRef] [PubMed]

59. Cadieux, J.; Roy, M.; Desmarais, L. A preliminary validation of a new measure of occupational health and safety. J. Saf. Res. 2006, 37, 413-419. [CrossRef] [PubMed]

60. Päivinen, M. Electricians' perception of work-related risks in cold climate when working on high places. Int. J. Ind. Ergon. 2006, 36, 661-670. [CrossRef]

61. Zeng, S.X.; Shi, J.J.; Lou, G.X. A synergetic model for implementing an integrated management system: An empirical study in China. J. Clean. Prod. 2007, 15, 1760-1767. [CrossRef]

62. Fernández-Muñiz, B.; Montes-Peón, J.M.; Vázquez-Ordás, C.J. Safety management system: Development and validation of a multidimensional scale. J. Loss Prev. Process Ind. 2007, 20, 52-68. [CrossRef]

63. Coleman, P.J.; Kerkering, J.C. Measuring mining safety with injury statistics: Lost workdays as indicators of risk. J. Saf. Res. 2007, 38, 523-533. [CrossRef] [PubMed]

64. Bevilacqua, M.; Ciarapica, F.E.; Giacchetta, G. Industrial and occupational ergonomics in the petrochemical process industry: A regression trees approach. Accid. Anal. Prev. 2008, 40, 1468-1479. [CrossRef]

65. Brooks, B. Shifting the focus of strategic occupational injury prevention: Mining free-text, workers compensation claims data. Saf. Sci. 2008, 46, 1-21. [CrossRef]

66. Duijm, N.J.; Fiévez, C.; Gerbec, M.; Hauptmanns, U.; Konstandinidou, M. Management of health, safety and environment in process industry. Saf. Sci. 2008, 46, 908-920. [CrossRef] 
67. Salla, L.; Kivistö-Rahnasto, J. Utilization of external accident information in companies' safety promotion-Case: Finnish metal and transportation industry. Saf. Sci. 2008, 46, 802-814. [CrossRef]

68. Nielsen, K.J.; Rasmussen, K.; Glasscock, D.; Spangenberg, S. Changes in safety climate and accidents at two identical manufacturing plants. Saf. Sci. 2008, 46, 440-449. [CrossRef]

69. Schrover, A.J.M. Ten years SHE-improvements on a chemical and nuclear research-site-Learning drivers. Saf. Sci. 2008, 46, 551-563. [CrossRef]

70. Zeng, S.X.; Vivian, W.Y.; Tam, C.M. Towards occupational health and safety systems in the construction industry of China. Saf. Sci. 2008, 46, 1155-1168. [CrossRef]

71. Komljenovic, D.; Groves, W.A.; Kecojevic, V.J. Injuries in U.S. mining operations-A preliminary risk analysis. Saf. Sci. 2008, 46, 792-801. [CrossRef]

72. Caroly, S.; Coutarel, F.; Landry, A.; Mary-Cheray, I. Sustainable MSD prevention: Management for continuous improvement between prevention and production-Ergonomic intervention in two assembly line companies. Appl. Ergon. 2009, 41, 591-599. [CrossRef] [PubMed]

73. Chang, J.I.; Liang, C.-L. Performance evaluation of process safety management systems of paint manufacturing facilities. J. Loss Prev. Process Ind. 2009, 22, 398-402. [CrossRef]

74. Santos-Reyes, J.; Beard, A.N. A SSMS model with application to the oil and gas industry. J. Loss Prev. Process Ind. 2009, 22, 958-970. [CrossRef]

75. Crippa, C.; Fiorentini, L.; Rossini, V.; Stefanelli, R.; Tafaro, S.; Marchi, M. Fire risk management system for safe operation of large atmospheric storage tanks. J. Loss Prev. Process Ind. 2009, 22, 574-581. [CrossRef]

76. Knegtering, B.; Pasman, H.J. Safety of the process industries in the 21st century: A changing need of process safety management for a changing industry. J. Loss Prev. Process Ind. 2009, 22, 162-168. [CrossRef]

77. Pasman, H.J.; Jung, S.; Prem, K.; Rogers, W.J.; Yang, X. Is risk analysis a useful tool for improving process safety? J. Loss Prev. Process Ind. 2009, 22, 769-777. [CrossRef]

78. Moriyama, T.; Ohtani, H. Risk assessment tools incorporating human error probabilities in the Japanese small-sized establishment. Saf. Sci. 2009, 47, 1379-1397. [CrossRef]

79. Fernández-Muñiz, B.; Montes-Peón, J.M.; Vázquez-Ordás, C.J. Relation between occupational safety management and firm performance. Saf. Sci. 2009, 47, 980-991. [CrossRef]

80. Celik, M. Designing of integrated quality and safety management system (IQSMS) for shipping operations. Saf. Sci. 2009, 47, 569-577. [CrossRef]

81. Reniers, G.L.L.; Ale, B.J.M.; Dullaert, W.; Soudan, K. Designing continuous safety improvement within chemical industrial areas. Saf. Sci. 2009, 47, 578-590. [CrossRef]

82. Baram, M. Globalization and workplace hazards in developing nations. Saf. Sci. 2009, 47, 756-766. [CrossRef]

83. Shengli, N. Ergonomics and occupational safety and health: An ILO perspective. Appl. Ergon. 2010, 41, 744-753. [CrossRef]

84. Gangolells, M.; Casals, M.; Forcada, N.; Roca, X.; Fuertes, A. Mitigating construction safety risks using prevention through design. J. Saf. Res. 2010, 41, 107-122. [CrossRef] [PubMed]

85. Cheng, C.-W.; Leu, S.-S.; Lin, C.-C.; Fan, C. Characteristic analysis of occupational accidents at small construction enterprises. Saf. Sci. 2010, 48, 698-707. [CrossRef]

86. Celeste, J.; Silva, C. A semi-quantitative assessment of occupational risks using bow-tie representation. Saf. Sci. 2010, 48, 973-979. [CrossRef]

87. Sgourou, E.; Katsakiori, P.; Goutsos, S.; Manatakis, E. Assessment of selected safety performance evaluation methods in regards to their conceptual, methodological and practical characteristics. Saf. Sci. 2010, 48, 1019-1025. [CrossRef]

88. Fera, M.; Macchiaroli, R. Appraisal of a new risk assessment model for SME. Saf. Sci. 2010, 48, 1361-1368. [CrossRef]

89. Lindhout, P.; Kingston-Howlett, J.C.; Ale, B.J.M. Controlled readability of Seveso II company safety documents, the design of a new KPI. Saf. Sci. 2010, 48, 734-746. [CrossRef]

90. Celik, M. Enhancement of occupational health and safety requirements in chemical tanker operations: The case of cargo explosion. Saf. Sci. 2010, 48, 195-203. [CrossRef]

91. Dawson, D.; Ian Noy, Y.; Härmä, M.; Åkerstedt, T.; Belenky, G. Modelling fatigue and the use of fatigue models in work settings. Accid. Anal. Prev. 2011, 43, 549-564. [CrossRef]

92. Pheng, L.S.; Kwang, G.K. ISO 9001, ISO 14001 and OHSAS 18001 Management Systems: Integration, Costs and Benefits for Construction Companies. Arch. Sci. Rev. 2005, 48, 145-152. [CrossRef] 
93. Romain, J.; Imbeau, D.; de Marcellis-Warin, N. Development of an indirect-cost calculation model suitable for workplace use. J. Saf. Res. 2011, 42, 149-164. [CrossRef]

94. Leka, S.; Aditya, J.; Widerszal-Bazyl, M.; Żołnierczyk-Zreda, D.; Zwetsloot, G. Developing a standard for psychosocial risk management: PAS 1010. Saf. Sci. 2011, 49, 1047-1057. [CrossRef]

95. Verna, B.; O'Keeffe, V. Weighing the pig never made it heavier: Auditing OHS, social auditing as verification of process in Australia. Saf. Sci. 2011, 49, 1014-1021. [CrossRef]

96. Vinodkumar, M.N.; Bhasi, M. A study on the impact of management system certification on safety management. Saf. Sci. 2011, 49, 498-507. [CrossRef]

97. Pernille, H.; Hasle, P. Making work environment auditable-A 'critical case' study of certified occupational health and safety management systems in Denmark. Saf. Sci. 2011, 49, 1022-1029. [CrossRef]

98. Ying, L.; Xingdong, L. A study on a new hazard detecting and controlling method: The case of coal mining companies in China. Saf. Sci. 2011, 49, 279-285. [CrossRef]

99. Zwetsloot, G.I.J.M.; Zwanikken, S.; Hale, A. Policy expectations and the use of market mechanisms for regulatory OSH certification and testing regimes. Saf. Sci. 2011, 49, 1007-1013. [CrossRef]

100. Frick, K. Worker influence on voluntary OHS management systems-A review of its ends and means. Saf. Sci. 2011, 49, 974-987. [CrossRef]

101. Granerud, R.L.; Sø Rocha, R. Organisational learning and continuous improvement of health and safety in certified manufacturers. Saf. Sci. 2011, 49, 1030-1039. [CrossRef]

102. Kristensen, P.H. Managing OHS: A route to a new negotiating order in high-performance work organizations? Saf. Sci. 2011, 49, 964-973. [CrossRef]

103. Zwetsloot, G.I.J.M.; Hale, A.; Zwanikken, S. Regulatory risk control through mandatory occupational safety and health (OSH) certification and testing regimes (CTRs). Saf. Sci. 2011, 49, 995-1006. [CrossRef]

104. Hasle, P.; Zwetsloot, G. Editorial: Occupational Health and Safety Management Systems: Issues and challenges. Saf. Sci. 2011, 49, 961-963. [CrossRef]

105. Fernández-Muñiz, B.; Montes-Peón, J.M.; Vázquez-Ordás, C.J. Safety climate in OHSAS 18001-certified organisations: Antecedents and consequences of safety behavior. Accid. Anal. Prev. 2012, 45, 745-758. [CrossRef] [PubMed]

106. Goh, Y.M.; Love, P.E.D.; Stagbouer, G.; Annesley, C. Dynamics of safety performance and culture: A group model building approach. Accid. Anal. Prev. 2012, 48, 118-125. [CrossRef] [PubMed]

107. Cheng, C.-W.; Leu, S.-S.; Cheng, Y.M.; Wu, T.C.; Lin, C.C. Applying data mining techniques to explore factors contributing to occupational injuries in Taiwan's construction industry. Accid. Anal. Prev. 2012, 48, $214-222$. [CrossRef]

108. Pinto, A.; Ribeiro, R.A.; Nunes, I.L. Fuzzy approach for reducing subjectivity in estimating occupational accident severity. Accid. Anal. Prev. 2012, 45, 281-290. [CrossRef] [PubMed]

109. Badri, A.; Nadeau, S.; Gbodossou, A. Proposal of a risk-factor-based analytical approach for integrating occupational health and safety into project risk evaluation. Accid. Anal. Prev. 2012, 48, 223-234. [CrossRef]

110. Luria, G.; Morag, I. Safety management by walking around (SMBWA): A safety intervention program based on both peer and manager participation. Accid. Anal. Prev. 2012, 45, 248-257. [CrossRef]

111. Fernández-Muñiz, B.; Montes-Peón, J.M.; Vázquez-Ordás, C.J. Occupational risk management under the OHSAS 18001 standard: Analysis of perceptions and attitudes of certified firms. J. Clean. Prod. 2012, 24, 36-47. [CrossRef]

112. Mawhood, J.; Dickinson, C. Rail Staff Fatigue - The GB Regulators Perspective on Managing the Risks; Dadashi, N., Scott, A., Wilson, J.R., Mills, A., Eds.; Taylor \& Francis: New York, NY, USA, 2012; pp. 337-346, Print ISBN 978-1-138-00037-7, eBook ISBN 978-0-203-75972-1.

113. Lee, S.-W.; Kim, K.-H.; Kim, T.-G. Current situation of certification system and future improvements of the occupational health and safety management system for loss prevention in Korea-Focused on KOSHA 18001. J. Loss Prev. Process Ind. 2012, 25, 1085-1089. [CrossRef]

114. Gnoni, M.G.; Lettera, G. Near-miss management systems: A methodological comparison. J. Loss Prev. Process Ind. 2012, 25, 609-616. [CrossRef]

115. Badri, A.; Gbodossou, A.; Nadeau, S. Occupational health and safety risks: Towards the integration into project management. Saf. Sci. 2012, 50, 190-198. [CrossRef]

116. Hamidi, N.; Omidvari, M.; Meftahi, M. The effect of integrated management system on safety and productivity indices: Case study; Iranian cement industries. Saf. Sci. 2012, 50, 1180-1189. [CrossRef] 
117. Hsu, I.-Y.; Su, T.-S.; Kao, C.-S.; Shu, Y.-L.; Lin, P.-R.; Tseng, J.-M. Analysis of business safety performance by structural equation models. Saf. Sci. 2012, 50,1-11. [CrossRef]

118. Wang, C.-H.; Liu, Y.-J. Omnidirectional safety culture analysis and discussion for railway industry. Saf. Sci. 2012, 50, 1196-1204. [CrossRef]

119. Zubaidah, I.; Doostdar, S.; Harun, Z. Factors influencing the implementation of a safety management system for construction sites. Saf. Sci. 2012, 50, 418-423. [CrossRef]

120. Abad, J.; Esteban, L.; Jordi, V. An assessment of the OHSAS 18001 certification process: Objective drivers and consequences on safety performance and labour productivity. Saf. Sci. 2013, 60, 47-56. [CrossRef]

121. Santos, G.; Barros, S.; Mendes, F.; Lopes, N. The main benefits associated with health and safety management systems certification in Portuguese small and medium enterprises post quality management system certification. Saf. Sci. 2013, 51, 29-36. [CrossRef]

122. Lo, C.K.Y.; Pagell, M.; Fan, D.; Wiengarten, F.; Yeung, A.C.L. OHSAS 18001 certification and operating performance: The role of complexity and coupling. J. Oper. Manag. 2014, 32, 268-280. [CrossRef]

123. Yazdani, A.; Neumann, W.P.; Imbeau, D.; Bigelow, P.; Pagell, M.; Wells, R. Prevention of musculoskeletal disorders within management systems: A scoping review of practices, approaches, and techniques. Appl. Ergon. 2015, 51, 255-262. [CrossRef] [PubMed]

124. Gopang, M.A.; Nebhwani, M.; Khatri, A.; Marri, H.B. An assessment of occupational health and safety measures and performance of SMEs: An empirical investigation. Saf. Sci. 2017, 93, 127-133. [CrossRef]

125. Cañamares, S.M.; Escribano, B.M.V.; González-García, M.N.; Barriuso, A.R.; Rodríguez-Sáiz, A. Occupational risk-prevention diagnosis: A study of construction SMEs in Spain. Saf. Sci. 2017, 92, 104-115. [CrossRef]

(C) 2018 by the authors. Licensee MDPI, Basel, Switzerland. This article is an open access article distributed under the terms and conditions of the Creative Commons Attribution (CC BY) license (http:/ / creativecommons.org/licenses/by/4.0/). 